University of Louisville

ThinkIR: The University of Louisville's Institutional Repository

Electronic Theses and Dissertations

1949

\title{
The handling of injury cases under the Workmen's Compensation Act of Kentucky.
}

William E. Biggs

University of Louisville

Follow this and additional works at: https://ir.library.louisville.edu/etd

Part of the Political Science Commons, and the United States History Commons

\section{Recommended Citation}

Biggs, William E., "The handling of injury cases under the Workmen's Compensation Act of Kentucky." (1949). Electronic Theses and Dissertations. Paper 2343.

https://doi.org/10.18297/etd/2343

This Master's Thesis is brought to you for free and open access by ThinkIR: The University of Louisville's Institutional Repository. It has been accepted for inclusion in Electronic Theses and Dissertations by an authorized administrator of ThinkIR: The University of Louisville's Institutional Repository. This title appears here courtesy of the author, who has retained all other copyrights. For more information, please contact thinkir@louisville.edu. 


$$
+25 \%
$$

UNIVELSITY OF LOUIBTILIE

\author{
THE HATLLIHG OH INJUIY CASES \\ UNEA I E WOENEI'S \\ COAPESATIOH ACT OF KE TUCHY \\ A LISBETALION \\ SUBLIIIEL IO T:W F CUITY \\ OF RE GIALU:TS SCEOCI OF \\ FIA UNIVETITY OF IOUIUTIIIE

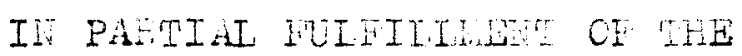

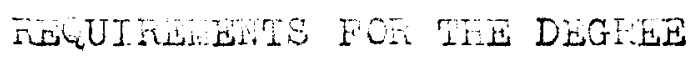 \\ OF MASTLF OF AFTS \\ DEPART LAT OF EISTOI AMD \\ FOLIIICAI SCIENCE \\ by \\ William E. Biges
}

YEAE

1949 


\section{UNIVERSITY}

LIBRARIES

This PDF document is a scanned copy of a paper manuscript housed in the University of Louisville (UofL) Libraries. The quality of this reproduction is greatly dependent upon the condition of the original paper copy. Indistinct print and poor quality illustrations are a direct reflection of the quality of materials that are available for scanning. The UofL Libraries greatly appreciates any better copies that can be made available for replacement scans. 
PATR OF STUDENT:

"i]linm E. Bires

TIII OT THSIS: The Handling of Injury cases $\therefore \quad$ Under the orkmen's

Compensation Act of Kentucky

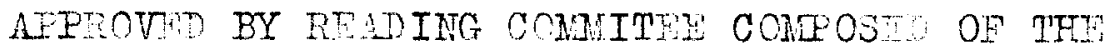

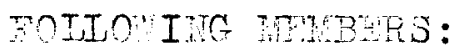

Revel G. Hemdahl

W. C. Mallalieu

NAMI OF IIRECTOR: Revel G. Hemdahl

nATE: Junel,194\% 
TABIE O F C O M E E IN $\mathrm{I}$

Introduction and conclusions...............

Chapter 1

The History of workmen's Compensation..........1

Chapter 2

The cost of Industrial Injuries............17

Chapter. 3

Provisions of the Kentucky Conpensation Act....25

Chapter 4

Eflects of the Kentucky act upon the Norker....49

Chapter 5

The Aoministration of the kentcuky Act.......72

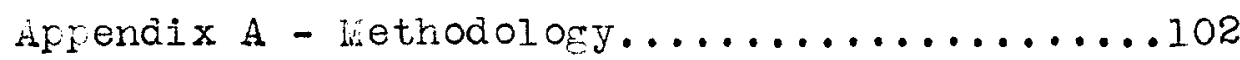


HANDLING OF: INDUSTEIAI INJUFIES

UNDEF THE WOKKMIEN'S

COMPENSATI ON ACT OF KLNTUCKY

\section{INTEODUCTION}

Prior to the adoption of the principle of workmen's compensation an employee who had recelved a work-injury could collect damages only by proving that the injury had been caused by the negligence of his employer. However, today the element of fault has been eliminated and the worker's right to receive momentary benefits depends prinarily on whether or not the injury arose during and out of the employment.

Workmen's Compensation was the first form of social insurance adopted in this country. Each of the separate states has now passed its own law on the subject, but in each of the laws the entire cost of the insurance is to be carried by the employer. These laws are based upon the theory that a large portion of industrial accldents are social in origin rather than individual and that the privations which frequently accompany an injury come not from the fault of the individual but from sources over which the individual has no control. It is upon this premise that the states have passed laws forcing, or strongly encouraging, the employer to insure their workers against industrial injuries on terms determined by the state. 
This survey proposes to study the administration of the Kentucky Workmen's Compensation Act and to learn, in so far as the state records show, the economic effects of the law upon the worker.

It is based upon a study of the records on file with the Workmen's Compensation Board in Frankfort, Kentucky, covering the period from July 1, 1946 to December 31, 1946. The choosing of the period for study involved several factors. An attempt was made to find a period which would furnish a large number of closed cases or else cases operating under an officially approved "open" agreement, and also a period which involved as broad a coverage of employers as possible. Since many of the most serious cases are left open for long periods, sometimes muning into jears, the use of a limited period in 1948 would not have included numerous serlous cases. Although a period prior to the last half of 1946 would have given an even greater percentage of such cases, nevertheless if such a period had been selected it would have ante-dated the important amendment to the Act which became effective June 19, 1946, which made operation under the provisions of the Act virtually compulsory for all hazardous employments, and thus greatly increased the number of employers operating under the Act. Thus the period selected combined the 
maximum coverage of workers with the maximum number of cases operating under signed agreements. The 1946 amendment caused an increase of approximately $30 \%$ in the number of employers carrying compensation insurance. ${ }^{1}$ It also increased coverage in the more dangerous occupations. In view of these facts the last half of 1946 was selected for examination. The limiting of this study to work accidents received by workers who come under the provisions of the Workmen's Compensation Act automatically excludes several large classes of employees: agricultural workers, domestic servants, and persons working for an employer who hires less than three persons. 2 It has been estimated that no more than half of the gainfully employed persons in the United States are covered by one of the Workmen's Compensation Acts. 3 It is impossible to tell the proportion in Kentucky but it is probably no higher than the proportion for the entire nation. Employers are not required to report to the Compensation Board accidents which incapacitate

1. An Increase from 13,083 for the fiscal year 1945-46 to 17,527 for the fiscal year 1846-47. Annual Report of the Department of Industrial Felations, Commonwealth of Kentucky, Fiscal Year 1946-47, p. 18.

2. Kentucky Revised Statuates (henceforth referred to as KFST 342.040

3. U.S. Bureau of Labor Standards, Bulletin 78(1946)p. 5 
the worker for less than two days and which do not leave any permanent injury. 4 These are usually called "Medical-only" cases because no disability benefits are paid in such cases, and the only expense to the employer, or his insurance carrier, is for the medical services furnished to the injured employee. Statistics for Missouri in 1931 showed that 70\% of the work injuries in the state involved no more than three days disability. ${ }^{5}$ Since the present study involves only the cases reported to the Board, a large portion of industrial accidents were eliminated because of the shortness of the disability. The practice among employers in Kentucky is to report to the Board only a few cases in which less than eight days is missed from work.

During the fiscal year of 1946-47, the Compensation Board received 19,307 reports of accidents in which there was either a permanent injury or an absence from work. 6 It is realized that some of the cases reported during the fiscal year occurped prior to July 1, 1946; nevertheless, based on these figures it is estimated that between 9000 and 4. KFS 342.040

5. Dodd, W. F., Administration of Workmen's Compensation, The commonwealth Fund (193), p. 620

6. Annual Keport of the Department of Industrial Relations, Op Cit, p. 18 . 
and 10,000 injuries occurred during the six-month period involved in this study. Since this was entirely too large a group of cases for intensive study, a sample of 339 cases was taken from the whole pertod and in intensive examination made of the files in these cases. The methods used in selecting these cases and the tests used in an effort to establish the proportionality and reliability of the sample are described in Appendix A.

Compensable infurtes are classified according to whether they are fatal, permanent, or temporary. The last two classifications are each subdivided into partial ana total disabilities. A death case is defined as one in which the injured employee dies from the infury recelved within a period of two years after the injury. A permanent total case is one in which the worker is completeIy and permanently incapacitated from engaging in any ordinary gainful employment. A permanent partial case is one in which the worker is left with a permanent impairment which will partially disable him in the future. A total temporary disabllity is one in which the worker is completely disabled from working for a period beyond the day on which the 
injury occurs, but from which a complete recovery is made without any residual permanent injury. A temporary partial injury is one which makes it necessary for the worker to do light work at reduced pay for a period. Only a small portion of the cases in this sample involved deaths or permanent injuries. In order to develop figures relying on a broader base, certain material was abstracted from the Register maintained by the Board on all cases occurring during the last half of 1946 which involved either of these two categories. The Fegister is a large ledger-style book which summarizes some of the more important facts from each case, such as the nature of the injury, the length of disability, the pay scale of the employee, and the total amount of disability he was paid. One line in the Register is devoted to each accident reported to the Board. However at the time the case is reported only a file number, the date of the injury and the names of the employer and employee are filled in. It is not until the case is later closed or a preliminary "open" agreement is filed by the parties and approved by the Board that the more pertinent information is inserted in the Register, and for this reas on the Register gives little or no information on a case in which no signed agreement has been filed. Even on the closed 
cases the Kegister does not show such information as the promptness and regularity with which the payments were made. The Kegister showed that in all there were 85 fatalities and 936 cases of permanent partial injury during the last six months of 1946.

The information obtainable from the Register was extremely limited. However when the entire file was examined in the 339 cases selected for a sample, far more intimate infornation was obtalned concerning the injured worker. The goal of this study was not to write a leaglistic study of one of the compensation laws. Instead an effort was made to look at the Kentucky Torkmen's Compensation Act from the level of the worker who has been infured and will receive benefits according to the provisions of the Act.

The general literature on the subject at the time that the various workmen's compensation laws were being adopted was that thiey should assure prompt pajment of benefits at a rate at or above the subsistence level to the injured employee, or to the dependents of those killed in industry, regardless of who was at fault in the accident. 7 In order to achieve this both the employer and the employee must 7. The report of the commission which drafted the 1914 Kentucky Act was not obtainable. 
give up certain old common law rights and recelve in return certain new rights which are based entirely upon the compensation statute. The employee gives up the right to sue for, and possibly obtain, unlimited money damages, but in return for making this concession he is relieved of the duty of proving that the employer was negligent toward him. On the other hand the employer loses certain legal defenses but he limits his exposure to that amount provided for by the state legislature. By the use of standard actuarial principles it is possible for the employer to predict in advance how much he will have to pay out in the form of benefits in any definite period of time and to add this amount to the cost of his product. In this manner much of the gamble is removed for all parties. ${ }^{8}$ The present-day acceptance of tine principle is shown by the fact that workmen's compensation legislation has been adopted by every state in the Union. 9 The minutes of the International Association of Industrial Accident Boards and Commissions (henceforth called I.A.I.A.B.C.) ${ }^{10}$ show

8. US Bureau of Labor Standards, Bulletin 78, (1946),

9. The Mississippi Workmen's Compensation Act went into effect in early 1948, making the acceptance of the system unanimous. Monthly Labor Review, September, 1948, p. 1

10. Published as bulletins of the US Bureau of Labor Statistics. 
that the idea has been endorsed by both organized labor anả organized capital.

After almost forty years of acceptance of workmen's compensation, the two most of ten debated questions today are: how wide a range of workers will be brought under the acts and how adequate shall be the disability payments made to the workers?

\section{CONCLUSIONS}

In order to study the Kentucky Workmen's Compensation Act from the view point of the injured workers who are affected by it, it was first necessary to find out who these 339 injured men and women were. Therefore the investigation sought to learn the worker's age, weekly wage, number of dependents, along with the nature of the injury received and the amount of benefits paid as compensation for the injury.

It was sought to learn both how the worker was affected by the Iaw as it was written and further to learn how the provisions of the law were altered in practice by the actions of the employer and of the Board. In the effort to discover the types of 
Injured workers involved, several facts were developed from the sample: the average age of the workers was 37.8 years and the average weekly wage was 46.79 . When the age was analyzed according to type of injury, the highest average age was among the fatal cases and the lowest was among the total temporary cases, indicating that it was the older worker who was most greatly affected by the 1946 amendment with regard to hazardous employments.

It was further indicated that $86.3 \%$ of the injured employees were married. Among the coal miners there was an average of 3.8 dependent children for each married miner, in the cases where the number of dependents were definitely given. Unfortunately it was limpos lbie to obtain figures on the number of dependent children in the other industries in the state.

In $85 \%$ of the cases the weekly benefit paid amounted to less than $65 \%$ of the weekly wage. There was a very definite correlation between high salaries and the more serious injuries. The average in total temporary cases was $\$ 45.51$; for permanent partial injuries it was $\$ 55.43$, and in the fatal cases talsen from the register it was $\$ 59.11$. When the distribution of the wage was made among the total temporary 
Cases it was found to be bimodal with a peak in the $\$ 30.00$ to $\$ 40.00$ range and a second, lesser peak in the $\$ 60.00$ to 70.00 a week range. This aifferential in the wage rate could be result of the degree of skill of the worker, seniority, unionization or nther factors. However, when the wage was charted in permanent partial cases, it rose irregularly to a single peak in the $\$ 60.00$ to $\$ 70.00$ a week range. The chart for the wage distribution in fatal cases was bimodal, but with the lesser peak in the 30.00 to $\$ 40.00$ a week range and the big peak in the 60.00 to 80.00 a week groups. Wien the amount of the weekIy benefit was contrasted with the average wages, it was found that the benefit amounted to $31.6 \%$ in the total temporary cases and $25.3 \%$ in the fatal cases. Due to the multiplicity of variables in the permanent partial cases no such calculation was fosible in tems 
of a percentage of the wage. 11

As a basis for comparing the effect of the amount of the weekly benefit on the standard of livIng of the injured worker, two government-prepared budgets for 1946 were examined. One of these was a family budget for city workers prepared by the U.S. Department of labor, which called for an income of $\$ 48.48$ a week. The other: was one prepared by the Kentucky Department of Industrial Relations for a working woman without dependents, which called for an incoule of $\$ 30.04$ a week. In adition to this, cognizance was taken of the minimum wage for women in Kentucly of $50 \not$ an hour, or $\$ 24.00$ a week. The minimum wage adopted as a subsistence level for women was the result of the above mentioned budget study.

11. The only similar study which could be found was one by Dr. Frank Horlacher which was incorporated in his book, The Effects of iorkmen's Compensation in Penns y Irania, Commonweal th of Pensylvania Department of Labor and Industry, Bulletin 40, (1934). It was based both on the records of the Pennsylvania Compensation Board and on interviews with the injured worker. This was done as a Civil Works project with a large staf'f of as istants. It attempted to discover how adequately the benefit payments had maintained the pre-accident standard of livirg. This study was made during a period of 1 ow wages and low employment. Therefore it is rather difflcult to compare the results of Horlacher's stuay with the figures for Kentucley during a period of high employment. Due to the limited time allotted to this study no efifort was made to interview any of the injured workers. 
When the average benefit payment of 477.35 a week in total temporary cases was compared with these three figures it amounted to $35.8 \%$ of the city family budget, $57.8 \%$ of the working woman's budget, and $72.3 \%$ of the minimum wage for women.

It is diffcult to compare the payments made in permanent partial cases because of the adòed variable of the degree of impaiment, which only indirectly affects his wage scale after his return to work.

However, when these three figures are compared to the weekly allowance to dependents in fatal cases, the average payment of 14.93 amounts to $30.8 \%$ of the family budget, $49.4 \%$ of the roman's budget and $62.2 \%$ of the minimum wage for women in Kentucky. The benefits which the injured workers were shown to have recelved were patently not adequate to maintain a family. Whether it was the purpose of the legislature in passing the Workmen's Conpensation Act to give benefit upon which the worker could furnish the bare necessitites of life to himself and his decendents or whether it was their intention that the benefit was to be only a partial help which must be supplemented from saving, 
borrowing or charity is a moot point. The average weekly wage of $\$ 46.79$ found in the sample is slightly lower than the $\$ 48.48$ minimum required by the budget designed for the family of the city worker. It is questionable whether such a salary permitted any great amount of saving, even when it is taken into account that Kentucky is not primarily an urban, manufacturing state. One can assume that in many cases there were but meagre savings and in some cases none at all.

If the benefits are raised, the added cost will in most cases be passed on the ultimate consumer of the goods and services produced, and Kentucky employerswill be placed in a more unfavorable competitive position with employers in other states. Fowever in event benefits fall below the subsistence level, the state must watch the worker go into debt or lise his savings and must be prepared eventually to bear the cost of relief of any worker who becomes destitute. These are factors which the legislative body must consider when it sets the policy on benefit rates.

An examination of the performance of his duties by the employer shured marked delays in making most payments. Althou ho paynent is cue until 
the 14th. day of disability, the average speed in making the first payment for all types of cases was 47.3 days from the beginning of disability. When this was divided according to the type of case the average delay was 41.3 days in fatal cases, 45.0 days for total temporary cases and 61.1 days for permanent partial cases. No permanent total or temporary partial cases were involved in the sample. 12

The regularity of subsequent payments is of as much importance to the worker as is the speed in making the initial payments. In $26.9 \%$ of the total temporary cases in the sample, prompt and regular payments were made when due; in $4.8 \%$ of the cases several payments were made, but at irregular intervals. In the remaining $68.3 \%$ of the cases no payment was made to the worker until after he had returned to work and he was then paid in full in a single payment. Within the last group mentioned approximately two-thirds, $44.7 \%$ of all the total temporary cases, involved a disability of less than 28 days. There are certain administrative difficulties

12. The f1scal report for 1946-47 listed only 11 cases of permanent total disability, which is less than $1 \%$ of the cases reported during the year. Among the cases abstracted from the Fegister three were coded for total fermanent disability but a closer examination of them showed that they actually involved permanent partial injuries. 
in investigatirg injuries occurring in outlying rural and mountain areas. In the last mentioned cases involving a disability of short duration, the practice of making a single payment after the return to work may be partially justified from an administrative standpoint. However in the remaining $23.6 \%$ of all the total temporary cases there was a disability in excess of 28 days and no rament made until after the return to work. This is an unnecessarily long delay, especially in view of the fact that the employee is receiving no pay during the disability and must depena upon his own resources to care for the day-to-day cost of living. 13

There was frequent delay in making a final settlement with the worker after he had returned to work. In permanent partial cases especially, a large part of tre benefit is frequentiy paid at this time. In all the cases in the sample the final settlement was made on an average of 76.7 days after the injury and 38.3 days after the end of the recuperation and the return of the worker to his job. As between

13. The practice with at least one large insurance company is to require a detailed letter of explanation from the adjuster in every case where the initial payment is delayed beyond the 14 th. day. Eowever this is apparently not a widespread practice. 
types of injuries the period varied from 23.2 days after return to work in total temporary cases to a period of 145.5 days after return to work in permanent partial cases. This last figure on the delay of final settlements in permanent partial cases is made as large as it is by the inclusion of four cases in which the facts were contested and a petition was filed for a hearing by the. Board. Part of the delay in those cases was the result of waiting for the administrative procedures of the Board and can not directly be attributed to the employer. If the cases involving litigation are not consiciered in the flgures there is still a delay of 118.4 days from the return to work until tre final settlement among the remaining permanent partial cases in the sample. There are several factors influencing and partially justifying this delay. In many of the cases the worker returns only to light duties before the maximum physical recovery is obtained and in many such cases the attendIng physician may have wished to wait for a period after the return to work before he would commit himself to a rating of the percentage of permanent disability, and it is not poseible to figure the amount due the worker for the residual permanent 
Injury until this rating is obtained. For instance, If an employes fractures a wrist he may be able to return to work on a light job in two or three months while the residual stiffness may continue to lessen slowly for a longer period. In such a case as this most àoctors prefer to wait at least until six months after the injury before making a firal rating of the permanent injury. This may partially explain the delay of 118.4 days in making the settlement. In these cases the worker has returned to the job and once more has a regular wage. In such a case the delay in giving a rating and settling for the residual injury does not work as great an economic hardship on the employee as does the delay in making pajments during the period he is unable to work. Among the cases in the sample there was an average delay of 32.7 days in reporting accicients to the Board after the disability began. There were also indications that in $47.6 \%$ of the cases reported to the Board, no further report was ever furnished the Board on the physical condition of the employee or on the amount of benefit paid. The failure on the part of the employer to furnish the Board with an original accident report anò a subsequent status report is 
subject to a small fine. However the failure to furnish a doctord report or a completed agreement between the farties regarding the amount of compensation agreed ufon is not subject to any such penalty. Perhaps if such a sanction were avallable to the Board, it would be more successful in obtaining enough irformation to enable it to close practically a1? its files, ratrer than juit $52.4 \%$ of trem, in two years ti...e.

An examination of the register showed that in less than $1 \%$ of all cases did trere develop a dispute between the parties leading to the filing of a petition for a hearing and decision by the Board on the merits of the case. However, these hearing cases constituted $5.9 \%$ of all fatal cases ana $6.2 \%$ of all the permanent partial cases. This indicates that litigation develops mainly in the cases where considerable money is at stake. iven anong the fatal and permanent partial cases this is an admirably low rate when compared to the common law system existing before the adoption of the Wormen's compensation.

Both the sample and the hegister showed that there was a large number of lump sum panients 
made in pemanent partial cases. The files showed trat many safeguards were established before a lump sum was authorized to a widow or de endent in a death case, but that there were no such safeguards in a permanent partial case where the injured morler himself was involved, and that any request for authorization of a lump sum payment coming fro a worker in a permanent partial: case received almost automatic approval without any examination being made by the Board of the uses to which the money was to be put.

The over-all results of the study indicates that the certainty of being compensated for an accident has been increased and that the contested claim has been reduced to less than $1 \%$ of the cases involved. However the maximum amount receiveable by the injured vorker or his dependents is below the subsistence level. The setting of a celling on the rate of benefits works the greatest hardship in the cases of the more serious injuries which are seen to occur among workers in the higher income levels, who have become accustomed to a standard of living well above the subsistence 1evel. The standard of wages in the state also would indicate that there is little 
opportunity for savings among the workers.

The examination of the performance of the employer or his insurance company showed that slowness in making initial payments was the usual procedure and there was a widespread practice in two out of three cases of not making any payment of compensation to the employec until after he had recovered and returned to wark. Once the employer has reported the accident to the Board he could with Impuntty delay in making the benefit payments to suit his convenience, since the Board had no means of requiring an accounting of the mamer of payment.

The literature on the subject of workmen's compensation indicates that an universal aim of all compensation laws is to as sure prompt and regular payment of tre benefits due. This is the evident intention of the framers of the Kentucky Act since they provided that once the seven-day waiting period had elapsed, the benefits should be paid on the regular payday of the employer, ${ }^{14}$ thus continuing the accustomed intervals of recelving income. Yet the Board is given no effective power to require

\section{KRS 342.040}


that this is done. The degree to which the requirement for reporting cases to the Board is observed indicates that there is a distinct advantage to putting sore teeth into the sections of the Act relating to procedures.

The work of the Board in uncontested cases has been merely to check the material furnished to It by the employer. It has had to accept the statements furnished with regard to the extent of infury involved and has merely checked to see if payments were made in a corresponding amount. Many cases are approved and closed with no medical information furnished and with no accounting of the promptness and regularity with which payments were made. Such a system sets a high premiun on the good faitr of the interested parties. Such a temptation is not good for the character of any man. 
CHAPTER I 


\section{CHAFTER I}

\section{THE HISTORY OF MHE WOFKHEN'S CORPENSATION MOVEMENT}

A mere recltation of statistics showing the number of injuries, the extent of injuries, the amounts of compensation awarded, and the number of contested and uncontested cases handled during the period from July through December 1946 would be without significance. In order to evaluate the social and economic results of the Kentucky Act, it is necessary to few the results obtained in terms of the objectives which the compensation plan tries to reach. In order to learn the objectives of any law it is necessary to learn its history and to learn the purposes and goals sought by persons responsible for 1 ts adoption. ${ }^{1}$ During the first two decades of the present century there was strong pressure of public opinion for the passage of Workmen's Compensation Laws in the United States and Canada. Hany writers and social reformers popularized its philosophy and urged its enactment. Legislature after legislature appointed commissions to study the subject and to recommend legislation. Suggestions for provisions were made by groups with varied interests in

1. Horlacher, Op Cit,p. 3. 
the subject. ${ }^{2}$ What were the objectives of these various people? In order to learn the objectives of these people it is necessary to learn the industrial conditions of their times with respect to the rights and remedies available to the injured worker. Only with such a background can the more recent results obtained under the Kentucky Act be judged.

During the early Nineteenth Century, the common law in effect in England and America followed the old Roman law of Fiespondeat Superior. Under this law, a master was responsible to third persons for injuries inflicted upon them by the negligent acts of his servants conmitted in the course of their employment. 3 This was based upon the theory that since the master received the benefit of their service he should bear the burden of their negligence. ${ }^{4}$

However, in England in 1837 an injured servant tried to apply this doctrine of law in a suit for damages against his employer for an injury received from a fellow employee while both were at work. This

2. Ibid, p. 3 .

3. Dodd, Op Cit, p. 4

4. Wharton on Negligence, p. 140 
was the famous case of Priestley V. Fow ${ }^{2}{ }^{5}$, which was decided by Lord Abinger. In an often quoted portion of this decision the judge stated:

"If the master be $I i a b l e$ to the servant in this action the principle of that liability will be found to carry to an alarming extent..... The mere relation of the master and the servant never can Imply an obligation on the part of the master to take better care of the servant than he may reasonably be expected to do of himself. He is no doubt bound to rrovide for the safety of his servant, in the course of his employment, to the best of his judgment, information and belief. The servant is not bound to risk his safety in the service of his master, and may, if he thinks fit, decline any service in which he reasonably apprehends injury to himself; and in most of the cases where danger may be incurred, if not all, he is just as likely to be acquainted with the probability and extent of it as the master"."

This decision which cut down on the responsibility of the employer came at a time when a great change was taking place in the use of powered industrial equipment. 7 It has been cited as an example of the individualistic tendency of the common law to assume that an employee was free to contract and was not bound to risk injury to himself in any particular job, and also as an example of the desire of

5. 3 Hees \& Wels. I (1837)

6. Quoted in Boyd, J.H., Workmen's Compensation, $(1913)$, p. 5 .

7. Dodd, Op Cit, p. 5 . 
judges to encourage large industrial establishments by making the burden on them as light as possible. 8

The Fellow Servant Fule thus established was quickly expanded to the Doctrine of Assumption of Fisk, namely, that a servant when he accepted employnent asumed all the orainary risks incident to his work. 9 Both these doctrines were quickly adopted by the American courts. In order for an employee to win a suit at law against his master he had to prove not only that the master had been negligent in scine way but that he himself was exercising ordinary care and was free of any negligence which was a contributing and proximate cause of his injury. 10 On the other hand tre employer had only the limited duties to furnish a reasonably safe place to work, to provide reasonably safe tools, of being reasonably careful in hiring agents or servants fit for the worls they were suprosed to do, of providing suitable and reasonable rules for the carrying on of the work, to use ordinary care and diligence in keeping the plant and its appliances in safe condition

8. Dodd, Op Cit, p. 7

9. Labatt, liaster ana Servant (1913) Vol. 3, p. 3102 10. Horovitz, S.B., Current Trends in Workmen's compensation, Tive Law Society of Mas sachusetts (1947), p. 467 
(in other words the duty of inspection and repair), and to warn and instruct youthful and inexperienced servants as to the danger of the rork. ${ }^{11}$ It might be inferred from this list of duties imposed on the emplojer that it would be easy for the injured worker to recover danages from the employer. Such however, was not the case; for the employee must prove with proper technical evidence:a violation of one of these duties by the employer and to get such testimory he generally had to depend upon his fellow employees as witnesses and they were usually reluctant to testify against their employer. In adition, the rules as to the employer's duties soon becane so ridaled with exceptions and fine-spun distinctions in the employer's favor that they gave the employee practically no protection. 12

As industrial and commercial enterprises grew in size and complexity, the e was an increase in industrial accidents and it became apparent that the law was operating too harshly on the claims of injured workers..$^{13}$ The Ohio court in $1851^{14}$ adopted the "vice-principle" exception to the fellow-servant

11. Boyd, Op C1t, p. 2

12. Dodd, Op Cit, p. 9

13. Ibid, p. 9

14. Littie Miami R.R. Co. V. Stevens, 20 Ohio 415 (1851). 
rule, whereby a supervising or directing employee was not a fellow servant and the employer could not use the defense of toe fellow-servant rule in escaping liability.

Prior to 1880, five states passed lams making rallroad companies liable to employees. 15 various states passed employer's liability acts takine from the employers the defenses of Assumption of Risk and Fellow Servant, 16 but it was still necessary for the employee to prove some measure of fault on the part of the master. It was still necessary for the employee to resort to slow and costly court action to obtain relief for his injuries.

There was considerable agitation in the United States during the administration of Theodore Koosevelt for more adequate laws dealing with industrial acciderts. The croundwork for this had been laid by the investigation of the German compensation system by John Graham Brooks published in the Fourth Special Keport of the Commiseioner of Labor of the United States 1n 1893. During the first decade of the present century Congress and the legislatures of

15. Georgia, Iowa, Kansas, Wisconsin and Nyoming 16. U.S. Bureau of Labor Bulletin 74 (1908) 
numerous states appointed comnis sions to study the subject of workmen's compensation and to inale recomnendations for laws on the subject. ${ }^{17}$ Exhaustive examinations were made by these commissions of the compensation laws then in existence in Germany and Great Britain.

The German plan was part of a general plan of social insurance. The, writings of Fichte and Hegel have been attributed with having strong influence on its development. Concerning these writers, it was said in the Fourth Special Report:

"The three laws of insurance against sickness, accident, and old age and invalidity confescedly rests upon a conception of society which is sharply opposed to what is 100 sely called ixdividualism, or laissez faire. In the mass of this insurance literature, the thought is constantly expressed that the weaker members of society will be excluded from all that accords with our usual sense of justice and fair dealing until the centers of social influence, of which the first and most powerful is the state, become imbued with the idea that a large proportion of the misfortunes, sickness, accident, and premature age are social in origin ratrer than individual; that a large part of these evils spring, not from the fault of the individual, but from sourges over which the individual has no control".

17. U.S. Bureau of Labor, Bulletin 92 (1911), p. 97 18. Boyd, op Cit, p 34 . 
Another writer 19 summarized the goals of

the German law as follows:

"The workingman, or his family in case of death, should be compensated in a reasonable amount for the consequences of industrial accident; not in order that someone shall be, mulcted on the grounds that he was at fault, but in order that this portion of the cost of the product or service shall not be transferred from the employer and the ultimate consumer to the workingman and his family, crushing them in many cases, and eventually shifting the burden to the community in the most undesireable form of charity".

Most of the states moved slowly in adopting compensation 1aws. By 1916, thirty-one states and the Federal Government had appointed commissions to investigate and report upon conditions and many of the states had adopted laws. 20 most of these commissions adopted a fact-finding procedure. The results of the investigation in New York, Ohio, Illinols, and Wisconsin and of a private study in Pittsburg by Crystal Eastian are summarized by Boyd:21

The fincings of the commissions developed four main objections to conditions as they were found to exist before adopting compensation laws.

The first objection was that only a small

proportion of workmen injured in industry received

19. Henderson, C.R., Industrial Insurance in the United States, (1909) p. 18.

20. $\frac{\text { U.S. Bureau of Labor Statistics, Bulletin } 423}{(1926), p \cdot 3}$

21. Boyd, op Cit, p. 60-68. 
substantial damages. Of 48 fatal cases in Manhattan in 1907 ano 1908, 18 families got nothing, 3 received \$100 or less, 18 received $\$ 101$ to $\$ 500,5$ received \$50I to 2000 and 4 were paid over $\$ 2000$, and 11 cases were still pending at the time of the report, only three families recovered as much as three times the Jearly wage. 22 The pittsburg survey showed that in $53 \%$ of industrial fatalities, the familybore the entire economic loss. In Ohio, only $36 \%$ of fatalities were compensated and in an average amount of $\$ 838.61 .24$ These various statistics indicated that in a large portion of industrial injuries there was absolutely no compensation paid in any degree, that in a large portion of cases where a recovery was made it was inadequate to make up the wage loss incurred, and that the system of suits at law was so uncertain that it was impossible to tell in advarce whether any recovery could be made and whether it would be large or small.

A second objection was the wastefulness of the system. The figures for iNew York showed that only $34.34 \%$ of what employers paid in premiums for

22. New York Commission Fieport, published as an appendix in Eastman, op cit. 23. Eastinan, op Cit, p. 12i. 24. Boyd, op cit, p. 65. 
Insurance to cover their common law liability was actually paid out by the insurance companies in the settlement of suits and claims. Even in cases where a recovery was made by the employee from the employer, or his insurance company, it was still necessary for the employee to pay an attorney's fee. In Illinois, the attorney's fees averaged over $40 \%$ and in ohio they were about $25 \%$. $^{25}$ In: Pennsylvania they averaged from $30 \%$ to $50 \%$. 26

The third objection was the delay in the operation of the system. In New York it took from six montins to six years and in Ohio it took two Years on the average to obtain a judgment in a fatal case. This delay made it all the more imperative for the injured employee to accept a small amount in order to obtain a fast settlenent of the claim. 27

A fourth objection was the antosonism bred between the employer and employee when the liability insurance company entered the scene. He could gain compensation only on legal grounds, since the insurance company did not feel any of the moral responsibility or sympathy that the employer mient have felt. 28

25. Boyd, OpCit, p.63,67

26. Eas tman, op cit, p. 121, note

27. Dodd, op C1t, p. 25.

28. Eas tman, Op Cit, p. 194 
All the reports of the commissions recontiended one under-lying principle, namely, that liability for Industrial accidents should be fixed on the employer regardiess of who was at fault in the acciaent.

After the adoption of the German Workmen's Compensation Law in 1884, there was a rapid adoption of the principle in various European countries. The English law was passed in 1897 and it was followed by much investigation of the subject in America. The first law passed on the subject in this country was the Federal Workmen's Compensation Act affecting employees in the government service, which was passed in 1908. However, the subsequent growth was rapid. Compensation laws were enacted in ten states in 1911, in three in 1912 and in elght in 1913.29 The original Kentucky Workmen's Compensation Act was passed in 1914. It made observance of the law compulsory for all employers, with a few listed exceptions. Shortly thereafter this law was declared unconstitutional before it had an opportunity to go into effect on the grounds that the

29. U.S. Bureau of Labor Statistics, Bulletin 2I0, (1916) p. 91. 
compulsory feature was a violation of due process of the law. 30 A new law was passed giving the employer an election as to whether or not he would work under Workmen's Compensation. This new Act went into effect in 1916. It received only slight changes, mostly with regard to amounts of disability benefit, until 1946 at which time it was made virtually compuls ory as to "hazardous occupations".

As an alternate to coining under the operation of the Act, the employer engaged in a hazardous occupation is required to furnish a bond or insurance policy guaranteeing the payment of any judgment obtained against him by the employee. ${ }^{31}$ The commissioner of Industrial Felations had a share in the drafting of the 1946 amendment. He assembled the interested labor leaders and insurance companies for a conference and acted as intermediary in, the reaching of an agreement on the terns of the changes. There has been little research in the area of the various pressures which have worked in the shapine of the Kentucky Act. Such a study might 30. Kentucky State Journal Co. v. Workmen's Compensation Board, $161 \mathrm{Ky} \mathrm{562,} 170$ SW 437 (1914)

31. $1946, \mathrm{C} 203, \operatorname{Sec} 1$, Effective June 19, 1946. 
reveal much concerning the realities of the legislative process.

Today, Workmen's Compensation Acts bave

been adopted in all the states and in all but ont of

the provinces of canada. There is a great variation

in the details of these various laws, but the results

sought were much the sare in all jurisaictions.

Some of these were set forth in the $1 \& 12$ report of the

compensation commissioners of the State of hashing-

ton $^{32}$ in which they expressed the hope that it would:

"Furnish certain, pronpt and reasonable compensation to the victims of work accidents and their dependents, $80 \%$ of whom have heretofore nad no rearess uncier cominon law rules;

"Free tre courts from tre delay, cost and criticism incident to the great mass of personal injury litigation heretofore burdening them. "Relieve public ana private charity of much of the destitution due to uncompensated industrial accidents;

"Lessen economic waste in the payments to unrecessary lawyers, witnesses and casualty corporations and tre expense and time loss due to trials and arreals;

"Suprlant concealment of fault in accidents by a spirit of frank study of causes, resulting in cood will between employer and operative, lessing the number of preventable accidents and reducing the cost and suffering thereunder".

These statements of desired results remain

32. \&uoted in U.S. Bureau of Labor Statistics Bulletin o 72 (1940) p. 5 . 
challenging today. However, it has been suggested that two adaitonal goals be adaed to the list:

"Provisions for adequate and immediate nedical treatment when injuries occur;

"Arrangeinents for rehabilitating workers who, because of their injuries are no longer able to follow their former occupations". 33

From the very nature of this study based only on the of icial recoras, it is not possible to tell whether the victims of accidents have had to resort to either public or private charity, nor can it be told how many employees have employed an attorney. to represent them in obtaining payment without filing a claim, nor is there any indication of what rehabilitation was done for the injured. However some clues have been found on the promptness, certainty and reasonableness of benefits paid, on the number of cases which have Involved litigation, and on the medical treatment furnished.

since the last war there ras been an increased interest in the problem of renabilitation of the permanently injured worker. Hany discussions on the subject appear in the proceedings of the InAssociation of Industrial Accident Boards and

33. Ibia, p. 6 
Commissions. Wany of the writers on tre subject hold that if the amount of payment made is reduced in accordance with the degree of rehabilitation effected, it will discourage the injured worker from cooperating in the rehabilitation frogram, and they advocate that he be conpensated in accordance with the degree of injury without regard to the degree of improvement obtained through such special care. on the other hand, the removal of this monetary incentive les ens tre willingness of the employer to participate. The United line Horkers Union, throurh its welfare fund, has undertaken considerable rehabilitation work, but tris has been aone outside the framework of the Kentucky Compensation Act. The economic theory which underlies workmen's compensation has been defined by Domney as the doctrine of occupational risk. 34 the princifle, nainely, that the "risk of economic lose through personal injury in the course of procuction shall be borne by industry itself". He further contends that the principle applies as well to occupational diseases 34. Downey, E.H., Workmer's Compensation (1924), p. 21. 
as it does to occurational injuries and that the compensation system should apry to all industries, all rersons employed therein and all personal injuries which arise in the course of the industrial process. It is only upon such a framework that it will be posible to judge how successfully tie objectives have been accomplished in Kentucky. 
CIIAPTEF 2 


\section{CHAPRET 2}

\section{THE COST OE INLUSTEIAI INJUNIES}

Industrial injuries in 1946 caused almost 16,500 deatrs, left 1,800 workens totelly anci permanently disablea from ever working again, left 92,600 workers witi sone degree of partial impairment which they will bear perminently. There were a total of 2,059,000 industrial injuries. An inoustrial injury as used in this grour of figures includes only accidents in which time was missed from work on a day or days subsequent to the day on which the accident occurred. 1

From an ecoriomic standpoint this anounts to an actual time loss of 44,700,000 man-hours. When thelost working-lif'e expectancy of the persons killed and permanently disabled is calculated there is a future econonic $10 \mathrm{ss}$ of $233,700,000$ man-hours, or a yeais employrient for 780,000 workers; nor does this include the cost of medical and rospital care for tre injurec workers.2

In social cost of the temporary injuries is snall in comparison with the costs of the deaths 1. Monthly Labor Review, October 1948 , p. 361 2. Ib1a, p. 361 . 
and perianent injuries. A death on tre average

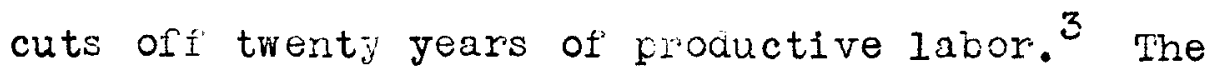
figures in this study show that the average age of the Kentucky worker who was illed to be 40 years and the age of those recelving serious permanent injuries to be 41.1 years of age. A permanent injury causes a cortinuing economic los $s$ based upon two variables: his age and the extert of his incapacity; the nature of the occupation of the worker is sometimes suggested as a third variable on this. 4 For instance a young worker coula more easily adjust to a new job after the loss of several fingers than could an elderly worker, anò an office worker could more easily adjust than could a manual laborer. The laws of some states vary the benefits with these adaeci factors.

The industrial safety mo:enent has macie considerable progress during the last ferr decades, but the experience during this time indicates that there is little prospect trat tilis los of life and productive capacity will be affreciably lessened. 5 Downey has summarized the industrial trend as follows:

3. Downey, op Cit, p. 1, 2 . 4. U.S. Bureau of Labor Statistics, Bulletin 359 (1924)

5. Downey, op Cit, p. 2. 
"The inherent trend of industry sets toward increasing scale, complexity and speed of operation, increasing use of machinery, increasing weight of materials and poducts, increasing substitution of unskilied for skilied workmen, and increasing control by absentee capitalists with an eye single to net profit - each an independent cause of greater accident frequency and all co-operating to enhance the hazards of industrial pursuits. In the face of these cumulative changes, all acting steadily in the same direction, 'Safety First" will dowell to hold its own over any ten-year period."

More and more, industry makes use of great working forces such as electricity, steam, explosives and chemical reactions. These must be kept in their proper channels in onder to keep tren useful ratrer than destructive. There is greater and greater use of high-speed machinery to which the worker must try to coordinate his movements. And the start has just been made in the utilization of atomic energy in industry. Certain workers accuire a greater degree of success in disciplining, thenselves to these changes, but the machines throw out old habits of thougnt and compel the adaptation of the workman to his work rather than the adaptation of the work to the worker. 7 The achievement of perfect adaptation

6. Ibid, P. 3

7. Veblen, T., Theory of Business Enterprise, (1904), p. $308-10$. 
would require that man become a robot which knew no fatigue or lapse of memory and responded automatically to every situation. Man is adjusted to a natural chythm, but one far slower ano more irregular than that of a machine, which leaves him imperfectly adapted to a mechanical environment; 8 for his adjustments are far slower than the rate at which the mechanization of industry:proceeds. Thus work injuries on a tremendous scale appear to be a permanent feature of modern life.

Studies of mass statistics show trat if a sufficiently large sample is taken it becomes possible to prodict fairly closely what percemtage of various types or injurles will be caused by varlous types of acciỏents in various industries. 9 Thus, at least $80 \%$ of permanent partial injuries in tire manufacturing industries will be injuries to the hands or fingers and there will be a highor rate of leg injuries in the logging industry than there will be in manufacturing. Thus it develops that each industry comes to have a fredictable inherent hazard. By using these figures every consumable

8. Downey, Op Cit, F. 7.

9. Monthly Labor Feview, Vol 67 (Oct. 1948), p. 364. 
commodity may be said to have a definite cost in terms of deaths or injuries - a life for so many tons of steel and a broken leg for so many thousand feet of lumber. 10

The consistency of these accicients raises the question as to who shall bear their economic costs. Will it continue to fall upon the worker who is injured or will it be distributed over society as a whole? If it $1 \mathrm{~s}$ to be distributed to society, what will be the standard used? One writer suggests the test of minimum social cost: "that distribution of unavoidable losses is to be preferred which imposes the least hardship upon the individuals and results in the smallest dinfnution of the community's economic assets". Il

Most industrial accidents occur to the worker who is employed at an hourly wage rather than on a monthly salary. Many of these live from payday to payday and accumulate little in the way of savings. The Pittsburg Survey showed that in the great majority of serious work accicients a family was deprived of its sole support, or at least its cheif support,

10. Downey, OpCit, p. 9. 11. Downey, Op CIt, p. 9. 
and that the result was poverty and a succession of misfortunes. 12

The situation had become so bad in the early days of the present century that more and more people advocated the adoption of workmen's Compensation Acts to proviae an adequate payment of disability benefits to the injured worker regardless of who was a fault in the accident which caused the injury. 13

There are today two basic theories as to the principle upon which these disability benefits are to be paid: ${ }^{14}$ The first, is that the cost of these payments shall be considered as a direct expense of production along with such items as wages, machinery and materials - that it should be standardized for a definite injury so that the future costs of compensation can be calculated and adcied to the cost of the product; the second, agrees that the cost should be passed on to the consumer but holds that the rate of benefit for a specific injury,

12. Eastman, Crystal, Work Accidents and the Law, The Pittsburg Survey, (1916), p. 73-78.

13. See Chapter 3

14. 28 I owa Law Review 38 (1942) 
such as the loss of a hand, should vary from person to person based upon the extent of his economic need after the irjury.

There are still many moot questions regarding what constitutes an adequate disability benefit. Shall it be geared to tine earning capacity of the worker before the injury? The various states have given I1p service to. this idea by settling the payments at a portion of the wage, varying from $50 \%$ to $70 \%$, but they have immediately nullified its effectiveness by placing a miximum ceiling on the amount of the payment, which, in $85 \%$ of the cases in this study, recuced to a lower percentage of the wage.

Shall the benefit be geared to the cost of livirg? If this be accepted as the basis, how high a standard shall be sought? In cases where payments are made over a period of years shall the rate be changed periodically in corformance with changes in the cost of living? Is the weekly maximum, if accepted, to aim at maintaining the worker at or below tile subsistence level? 
Unless the state $1 \mathrm{~s}$ prepared to bear part of the living costs of the injured worker in the form of public relief payments, then the rates for disablitty benefits should be raised to a point where the worker can maintain himself and his dependents independertly of public and private relief sources. 
CHAPTE: 3 


\section{CHIAPTER $\quad 3$}

\section{ANALYSIS OF THE KENTUCKY \\ WORKIEN'S COUPENSATION ACT}

If the principle of workmen's compensation were carried to its broadest limits, it would cover the loss of earnings caused by all personal disablements. (whether caused by accident or by industrial disease), ${ }^{1}$ which are incident to the production of economic goods and services; ${ }^{2}$ it would cover all industries, all persons employed therein and all personal injurtes arising in the course of employment. 3

The Kentucky Act is not designed to cover wage losses due to unemployment or old age nor is it designed to serve as a system to insure against ordinary illness, as distinguished from injuries. The Act does not cover all employrents, since the employers of agricultural laborers and domestic servants are specifically exenpt from being required to accept the Act. The same applies to employers who hire less than three persons regardless of the hazard of the

1. Rubinow, I.M., Social Insurance, (1910), Chapter 1. 2. Downey, Op Cit, p. 21 . 3. Wonthiy Labor Review, September 1919, p. 36. 
work; however, in all cases the employer may voluntarily elect to come uncier the provisions of the Act. 4 The exclusion of agricultural and domestic employees is found in the provisions of many state compensation laws. This has been criticized as resting on no consistent principle such as degree of hazard, frequency of accident or econanic need. 5 The usual reas on given for such exclusions is the administrative difficulty of covering a great number of farmers and small employers, but actually the exclusion is the result of the opposition of famers and horne owners who have objected to the expense as well as the bother involved in carrying compensation insurance. ${ }^{6}$ It has been shown amply that house work and farm work are hazardous; in 1947 there were more fatalities in agriculture than in any other major industrial group. 7

It is now proposed to review the various provisions of the Kentucly Workmen's Compensation Act

4. KRS 342,005

5. Downey, op Cit, p. 22

6. U.S. Bureau of Labor Standards, Bulletin 78, (1946) 7. Monthly Labor Review, October 1948, p. 361. 
(henceforth referred to as the Act) and to compare it with the similar lams of otner states. Unless otherwise indicated, all references in the present chapter are to the various workmen's compensation laws of the nation as they were in effect during the latter half of 1946.8 In cases where the Act was anended in 1948, reference will be made in the past tense.

Compensation laws may be classified as complus ory or elective. A compulsory law is one which requires every employer who comes within the scope of the law to accept tts provisions and pay the benefitis specified. Thereas, as elective act is one in which the employer has the option of either accepting the act or rejecting it, but in case he rejects the Act, he loses the customary common law special defenses (as sumed risk, negligence of fellow servant and contributory negligence); however, it is still necessary for the employee to establish that the employer was guilty of ordinary negligence. 9

8. A more detalled summary of the various laws is in U.S. Bureau of Standaras, Bulletin 78 .

9. U.S. Bureau of Labor Standards, Bulletin 78, (1946), 
Prior to the summer of 1946, Kentucky operated under an elective system. However the anendment of the Kentucky Act, effective June 19, 1946, took a long step in the direction of making the Act compulsory. It defined certain occupations as being "hazaraous" and the definition was sufficiently broad that it covered all workers who had to work with machinery. It specifically stated that sales work and clerical work were not hazardous, but the definttion included practically every other job. Of course the groups such as farm and domestic workers who were exempt from the entire scope of the Act were not affected by the provisions regarding hazardous employment.

The amendment required that all employers in these hazardous occupations must either come under the operation of tire Act or else file with the Department of Industrial kelations an indemnity bond or insurance policy insuring the payment of any judgment obtained by an employee or his dependents for damages resulting from personal injury or death by an accident arising out of or in the course of the 
employment. The size of the bond or insurance policy is set by the oommissioner of Industrial Relations based upon the number of employees and the hazard of the employnent. 10 Even though the employer complies with these provisions he is still deprived of the special common law defenses previously mentioned. 11 very stiff penalties are provided in case an employer engaged in a razardous enterprise falis to meet one or the other of these alternatives. ${ }^{12}$ To make sure that benefit payments will be made when due, the employer operating under the Act is required to obtain insurance with a properly qualified insurance company or else give proof of his financial ablitty to pay directly the benefits which shall become due. In the latter case tire Board requires the posting of satisfactory security to assure the payment of compensation liabilities as they are incurred. 13 Generally, only the largest employers are able to satisfy the financial requirements of the Board and become "Self-insured".

The Kenucliy Act sets up limitations not only as to the persons covored, but also as to the

10. KRS 342.016

11. KRS 342.006

12. KRS 342.990

13. KRS 342.340

(6) (7) and (8) 
injuries covered. Injuries caused by a willful, self-inflicted injury, by willful misconduct or by intoxication of the employee do not entitle him to receive the benefits of the Act. ${ }^{14}$ A compensable injury is defined as one "sustained by tho employee by accident arising out of and in the course of the employment". 15iost other states have some similar wording. As simple as the wording may seem to be, the courts and administrative bodies have tried to make so many distinctions as to what constitutes an industrial injury that it is impossible to give any clear universal definition. ${ }^{16}$ A few examples will illustrate the complexities: Is the development of pneunonia from exposure while at work an injury by accident? Is an injury recelved while on the way to work to be considered as occurring in the course of the employment? If a worker's shoe mabs a blister on his foot while at work and the blister later becones infected, does this arise out of the employnent? In borderline cases such as these the contradictory decisions are legion. No effort will be made in this study to go into the technical aspects of the legal

14. $\mathrm{KRS} 342.015$ ( 3 ).

15. KRS 342.005 (1).

16. 15 Wisconsin Law Review 37 (1931), by Dr. R.A. Brown. 
interpretation of the compensation law. However, reference is made to Horovitz's recent book for a very complete study of current legal trends. ${ }^{17}$

Although the tendency in many states is to cover occupational diseases, the Kentucky Act expressiy states that "injury by accident" shall not include disease except where the disease is the natural and direct result of a trauratic injury by accident, nor shall it include the results of pre-existing disease, unless incurred while on active duty in the army during wartime; the only exceptions are infury or death as a result of breathing poisonous gasses in a mine 18 and the contracting of silicosis. 19

The total amount which an injured worker receives under the Act is affected by the weekly rate, the term or period of payment, the weekly maximum and the aggregate maximurn. The amount and period of payment also differs according to the type of injury. The Act prescribes special provisions and procedures for death cases, for permanent injury cases and for temporary injury cases.

17. Horovitz, Op Cit.

18. KRS 342.005(1).

19. KRS 342.316. 
In no state does the employee receive his entire wage while he is disabled. It is customary for the rate of payment to be only a portion of the weekly wage, ranging from 50\% to $70 \%$ in varlous states. In Kentucky the rate is set at $65 \%$ of the Wage. However, the Kentucky emplojee does not always recelve this high a percentage of his wages because the Act puts a limit on the maximum weekly payment he can receive. In cases where a permanent total or temporary total disability is involved the maximum payment was set at $\$ 18.00 \mathrm{a}$ week, and in the cases of death or partial pemanent disability the maximum was $\$ 15.00$ a week. ${ }^{20}$ When earnings are relatively high theweekly maximum payments are only a small fraction of regular wages. It is proposed to study the range of this percentage in a later chapter of this survey.

20. All these figures regarding weekly maximums are the ones in effect in 1946. They were all increased $15 \%$ to $20 \%$ by the 1948 amendment to the Act. Reference is made to the last page of this Chapter for the exact 1948 rates. 
In addition to the maximum placed on the weekly rate of payments, a limitation is place on the number of weeks for which benefits will be paid. It is 400 week in death cases, 520 weeks in permanent total cases and 420 weeks in non-schedule permanent partial cases.

There are several arguments which are frequentIy used against the giving of large disability benefits. One of these is that the payment of full salary during the period of disability will promote malingering. Since human nature is what it is, most people would gladij stay home and receive fuli pay; all students agree that, at least in the case of total temporary disability, only a portion of full wages chould be paid during the disability. The above argument is not as valid when used against the payment of full wages in the case of total permanent injury. Another objection to full payment is that the worker will grow careless in his work and ignore safety mules and needlessly expose himself to danger. 21

Since disability benefits in cases of death

21. Dowrey, Op Cit, p. 37 
and permanent injury are so etimes paid for a period of years after the injury, the suggestion has sometimes been made that the weelrly rate of payments should fluctuate wit the current wages ard cost of living. However, in practice, the periodic revision of awards for death and permanent injury would involve tremendous administrative difficulties and it would stimulate litigation. Because of these factors, the rate based on the wages of the morker at the time of the injury is almost universally taken as the best basis for disability payments. 22

The amount of the employee's wages is only one of the variables in determining the scale and duration of benefits to be paid. The severity of injuries falls into three main classifications: death, permanent injuries and temporary injuries. Each of these classes offers problems so peculiar to itself as to require separate treatment under the Act. For instance there is greater possibility for malingering in the less severe temporary cases. This requires safeguards which are not needed in a death case or an amputation case.

22. Ibid, P. 39. 
Although death and permanent disability cases make up but a small portion of all injuries, yet in total costs they involve more than two-thirds of all disability payments made. 23

In the case of a fatal injury, the economic loss falls on the family of the deceased. Socially, the measure of the loss is the productive capacity of the deceased reduced to terms of working life expectancy. The amount of need resulting from the death w1ll vary with the number, age and family relationship of the dependents. In Kentucky, payments were made to dependents at the rate of $\$ 15.00$ a week for a maximum of 400 weeks for a total maximum benefit of $\$ 6000.00$. In 11 states the amount of the weekly payments varies according to the number of children and in 17 states the widow receives a life pension unless she remarries; however, there is no such provision in Kentucky. 24

In Kentucky an effort has been made to simplify the procedure for establishing derendency. The Act legally presumes that a wife and children

23. Dodd, op Cit, p. 620-22. 24. U.S. Burenu of Labor Standaras, Bulletin 78, (1946), p. 16-18, Feference is made to Eulletin 78 Por more detalled information on all states. 
under the age of 16 jears, living with and supported by the deceased at the time of death, are wholly dependent upon the deceased. In such cases it is only necessary to furntsh the proper mariage and birth certificates in order to validate tineir claims for bonefits; in all other cases the relationship of dependency in whole or in part shall be determined in accordance with the facts of the case. 25

In cases where some other relative was proven to be only partially dependent upon the deceased, he received a proportional share of the $\$ 15.00$ a week for the full 400 weeks; in other words, the amount of the weekly payment rather than the duration of payments is reduced. In cases where it was established that no one was even partially dependent upon the deceased, a small payent of $\$ 100.00$ was made to the "personal representative" of the deceased to cover incidental expenses of the estate. This last situation usually arises in the case of young unmarried employees. In death cases, an allowance of $\$ 150.00$ is also made toward defraylng funeral expenses. This last payment is made regardess of 25. KRS 342.075 . 
whether or not there are dependents. 26

Thirty-one states have simfiar provisions

and plece limits both on the size of weekly payments and on the duration during which payments will be made. However, seventeen states place a limit on the weekly amount but leave the duration of the payments as a variable depending on the length of widowhood and of the minority of the chiloren. 27

For the past fourteen years the U. S. Secretary of Labor has called an annual conference of representative of labor organizations, appolnted by the govornors of the states, for the discussion of matters of policy in the acministration of all labor laws. Both this National Conference of Labor Legislators and the A. I. A. I. B. C., which deals exclusively with the problems involved in workmen's compensation, have recommended that benefits be paid at the rate of $60 \%$ of the ceceased's wage, without any maximum, to the widow for life (or until remarriage) or to the chilaren until they are 18. However, to-date none of the states have adorted such a broad

26. KRS 342.070 .

27. U.S. Bureau of Labor Standards, Eulletin 78 , (1946), Table 4 . 
$\operatorname{plan} 28$

No effort has been made in this study to examine the effects of the increased costs which would result to the emploser, and eventually to the consumer, if more liberal benefits were made payable. This is a subject which is far beyond the scope of this faper.

Permanent disablities are generally divided into pemarent total and permanent partial. 29 Fermanent incapacity for ordinary employment is the test of permarent total incapacity for compensation purposes; it 1s enough if he is unable to follow any ordinary gainful occupation, even though he may be able to do occasional oda-jobs. ${ }^{30}$ No case of permanent total disability was found in the sample. The Act conclusively presumes total permanent disability in cases of blindness of both eyes, the loss of both hands at or above the wrist, the loss of botin feet ator above the ankle, the similar loss of one foot and one hard, a spine injury resulting in permanent paralysis of both arms of both legs or one of each, or an injury of the skull resulting in incurable insanity. In allicases the burden is 28. Wionthly Labor Feview, oct 1940, p. 545. 29. U. S. Bureau of Labo: Statist1cs, Bulletin 359, (1923), p. 20 . 30. Downey, Op C1t, p. 43 
on the employee to prove total remanent incapacity. 31 The employee who is so classified recelved wekly benefits of $\$ 18.00$ for a period of ten years for a maximum of $\$ 9,000.00$.

Most states have sorne limitation on the duration and amount of weekly payments in total permanent cases, although the payments are generally of longer duration than in the case of death. 32 Here also it is argued that such limitations defeat the purpose of compensaticn and cut of $f$ benefits when they are netded most. 33 Festrictions on the amount of the weekly payment are more serious in these cases than they are in death cas es because the disability of the injured employee requires that be receive support and frequentiy extra medical and nursing attention during the rest of his life. Only a few states allow extra benefits when a constant attendant is needed. 34

When one enters the field of permanent

31. KRS 342.095.

32. U.S. Bureau of Labor Standards Bulletin 78, (1946), pp. 19-20.

33. Dodò, Op Cit, p. 639.

34. U.S. Bureau of Labor Standards Bulletin 78, (1946), 
partial injuries, entirely new problems artse. The loss of an arm would be far mort of a handicap to a particular individual than would be the loss of one eye, but it is difficult to set up any standand as to whether it is $50 \%$ or $150 \%$ more disabling. From another arigle, the los: of an arrn would be more disabling to a manual laborer than it would be to a lawyer or a teacher. Definlte recommendations for a relatively scientific schedule of benefits for permanent partial injuries were outlined in 1922 and 1923 by a commt tee of the I. A. I. A. B. C. 35 They attempted to establish a relationship between the disabling effect of an arm injury and an eye injury, for instance. They also recommended that the benefits vary not only with the nature of the injury but also with the age of the employee. This was based on the theory that a younger man would better be able to adjust himself' to a new occupation than would be the older man. However, there has been no effort in Kentucky, or in most of the states, to conform to these recommendations.

35. U.S. Bureau of Labor Statistics, Bulletin 333 , (1922) $\mathrm{pH} \cdot 70-96$. 
The Act has set up a schedule governing the amount of benefits payable for permanent injuries to various members of the body. The weel-1y pagment was set at $65 \%$ of weekly wages up to a maximum of \$15.00. The number of weeks payable varies with the nature of the permanent injury: the amputation of or los: of use of a rand entitles tre employee to this benefit for 150 weeks; the same for an index f'inger, 45 weeks; for a thumb, 60 weeks; for an arm, 200 weeks; for a foot, 125 weeks; for a leg, 200 weeks; and the loss of sight of ons eye, 100 weeks. The schedule further elaborates with regard to the other fingers and the toes. 36

In all other cases of permanent partial injury not listed in the schedule, the benefits shall be determined according "to the percentage of disability, taking into account, among other things, any previous disability, the nature of the physical disability or disfigureent, the occupation of the injured employee and age at the time of the injury. 37 The non-schedule section is generally applied to injuries of the spine and lead and otker injuries which affect the body as a whole rather than a limited portion of it. In the case of "non-schedule" 
permanent partial infuries, the maximum weekly payment was set at 12.00 ratier than the 15.00 a week for schedule injuries, and the duration of the payments was limited to 420 weeks with an aggregate limit of $5,000,00$. Thus if an employee were totally and permanently disabled from working he could receive 18.00 a week for 10 years (maximum, $\$ 9,000.00), 38$ but if he were rated $b_{y}$ the doctors as being only $95 \%$ permanently disabled he could receive orly $95 \%$ of $\$ 12.00$ a week for 420 weeks, or an aggregate of 4788.00 . Thus from these figures it can be seen what a great advantage it is to the employer, or his insurance compeny, to have disability rated at a high degree of permanent partial disability rather than as a permanent total disability.

\section{All states have estaklished schedules}

stating the number of weels during which benefits shall be payable for specific injuries. The principle underlying these schedules is that it is to the advantage of the worker to know definitely what aid to defend upon after an injur. A life pension is 38. HES 342.095. 
given in only one state for it is generally supposed that a worker can adjust himself to his hancicap and recover his place in industry within a given time. 39

In the random sample usea in this study they conprised $16.3 \%$ of the cases. These of course rarge in degree all the way from minor impairments, such as the loss of a poution of one finger to nearly tótal loss of earning capacity.

The rate and duration of benefits for schedule injuries varies widely from state to state. The standards have been adopted in a hit-or-miss fashion so that tre benefits provided besr little relation either to the needs of tie injured employee or his dependests or to the loss of earning power resulting from the injury. 40 It is sometilies argued that these variations are the result of variations of ware standarcs from state to state. However, this does not seem to justify the wide variations in the maximum weekly payments, which range all of

39. U.S. Bureau of Labor Standards, Bulletin 78, 40. U.S. Bureau of Labor Statistics, Bulletin 333, 
the way from 12.00 to 30.00 in various states, nor the variations in duration of payments which vary for the loss of an arm all the way from 200 weeks to 500 weeks, 41 compared with 15.00 a week for 200 wecks in Kentucky for the los of an arm.

A problem also arises as between compensation for temporary and for permanent injuries. A nu ber of states allow benefits at the higher total temporar., rate during the healing or recuperating period in addition to payments for permanent partial disability. This is done on the principle that the healing period varies greatly from person to person on the same type injury, especially where an infection develops. Thus by paying separately for the healing period the worker is not penalized for variations in the healing period. Under the Kentucky Act as it stood in 1946 the schedule payments were exclusive and no provision was made for the realing period. In other words, tre number of any payments made at the higher rate during the healing period were substracted from tre number due for the permanent partial injury.

41. U.S. Bureau of Labor Standards, Bulletin 78 , $(1946), \mathrm{p} .30$. 
The Act required the employer to furnish necessary medical care up to a maximum cost of 400.00 . The employer is given the choice of selecting the aoctors, hospitals, etc, although the workmen's compensation Board is given the authority to order any necessary changes whenever there is reas onable grounds to believe that the health or recovery of the employee is being endangered. 42

The Act provides that for the first seven days immediately following an injury, no benefits shall be payable to the worler. ${ }^{43}$ The justification for this "waiting period" is the cost and administrative burden of setting up claim files and accounts where only a few dollars will be disbursed. The waiting period applied only to benefit payments. Miedical and hospital care is provlded regardless of the fact that compensation is not paid for a specific period. Fowever if the disability continued for more than four weeks the payment of benefits is retroactive to the date of injury. ${ }^{44}$

42. KRS 342.030 .

43. KRE 342.040 .

44. U.S. Bureau of Labor Standards, Bulletin 78, 
Where an employee has sustai ed an injury involving the loss of a member of the bocy and loses another as the result of a subsequent industrial injury, he may become totally ano permanently disabled thus increasing disproportionately the amount of benefits to be paid by the last employer. This makes it difficult for an injured job-hunter, such as an injured veteran right after the war, to obtain a job. A 1946 amendment to the Act limits the amount chargeable to the employer to the usual award that woula be paid alone for an injury of the type last received, regardless of the actual cisability resulting from the combined injuries. The differential is paid to the worker out of a "subsequent-irjury fund" maintained by the state. 45 Thus in a case where a worker is already blind in one eye and loses the sight of the secord eye in an accident, the employer is liable only for $\$ 15.00$ a week for 100 weeks, even though this is a total permanent case entitling the employee to $\$ 18.00$ a week for ten years. The amount which the worker had received, or might have received if the first injury had been compensable, is deducted from the amount whicis is payable out of the subsequent45. KFS 342.120. 
Injury fund; in this case the worker would get $\$ 1500.00$ from the employer and $\$ 6,000.00$ from the fund. The subsequent-injury fund is supported by a tax levied against every insurance carrier of $3 / 4$ of $1 \%$ of premiums received in the state. A tax of proportional amount is levied on self-insured employers. In the metrod of supportine the fund, the Kentucky Act differs from the recominendation of: the I. A. I. A. E. C. that each employer pay $\$ 500.00$ into the fund each time they have a death case in which no dependents are left by the deceased. 46

In the proceding portion of this chapter the provisions of the 1940 Formen's Compensation Act have been used. It should be noted that several clanges, effective June 30,1948 , have been made in the law. The weekly maximum for total temporary and for total permanent disability was raised from $\$ 18.00$ to $\$ 21.00$, and $15.00^{\text {rtin }}$ to 18.00 and the maximum duration in these cases increased from 420 weeks to 450 weels; the maximum medical expense chargeable to the employer was increased from $\$ 400$ to $\$ 500$, with authority 46. Montriy Labor Feview, October 1946, P. 546. 
given to the Board to increase it to 800 in certain cases; the ailowance for burial expenses was increased from $\$ 150$ to 300 ; the allowance to the personal representative in cases where there were no dependents was increased from $\$ 100$ to $\$ 200$; an allowance of 75 weeks compensation at 18.00 a week for the loss of hearing in one ear was added to the schedule for permanent partial injuries; and provision was mace for the payment of $\$ 21.00$ a week for the healing period, up to a maximum of 20 weeis, in acaition to payments for permanent partial aisability.

These changes were timerily increases in weekly payments designed to cover the rising cost of living since 1946. Only the change regarding the healing period showed any alteration of bacic theory. 
CIAPTLE 4 
CEAPTEF 4

\section{EFFECTS OF THE KEIVIUCKY ACT \\ UPON TIE EUPLOYELS COVERED}

The files in the sample were studied first from the standpoint of how the provisions of the Act, as written, affect the wor er who comes witin its scope. The problems of how the provisions of the Act are altered in practice by the activity, or inactivity, of the employer and of the Board will be covered in tine next chapter.

First, a check was made to determine who was the worker who has been injured. Fow old was he? What was his weekly wage? How rlary dependents was he suprorting? What was the nature of his injury and what total benefits did he receive?

A check of the 330 cases used in the randomly selected sample revealed that tre file did not show the age of the worker in 23 of the cases. In thu remaining 316 cases the average was 37.8 years. When the d ta was analyzed as to the typ of injury the distribution was 35.7 jears for th temporary total cases, 38.4 yeans for the permanent partial cases and 41.5 years for tre fatal cases. 
A distribution of the cases according to type of injury showed that there were 281 , or $82.7 \%$, total temporary cases; 55, or 16.2\%, pemanent partial cases, ana 3 , or $0.9 \%$, death cases.

Since such a small number of deati cases were included in the sample, a check was made of tre information abstracted from the Register on the 85 death cases occurring during the entire six months time. This showed an average age of 40.0 , which is lower than the figure obtained from tho sample. A check of tre Register also showed that ir the 103 most sexious pemarent partial cases (those in which there nas a total benefit of more than 41000.00 paid) the average age was 41.1 years. in se figures are in conflict ith Downey's theory that it is the jouncer-than-average man who is more daring and is hired for the more dangerous jobs and receives the more serious injuries. ${ }^{1}$ one possible explanation is that there is a hich percentage of more serious injuries occurring in the mining industry and it is in this ircustry that there is a high degree of unionization which helps assure tenure.

1. Downey, Op Cit, p. 2 . 
Also the pension plans for miners tend to keep then from wandering to some other industry. Although 16.2\% of the cases in the samplo were permanent partial injuries, a check of the 125 cases in the sample of injuries to mikers showed that $23.2 \%$ of thom left permanent partial injury. Wren cheched from another angle it was shown that mining injuries constituted $30.7 \%$ of the cases in the.sample, but that $52.7 \%$ of all permanent partial injuries in the sample occurred to miners.

A word of caution shoula be spoken wit? regard to the proceding figures on mining accidents. Although the records of the Forkmen's Compensation Board are coded according to the industry in which the injury occurs, this fact was rot knom to the writer until after the files had been examined. Because of the lack of suficient time the files were not re-examined to obtain this infornation. The figure of 125 mining accidents in the sample is based upon internal evidence in the file: most mining companies use a specially printed accident form for reporting accidents, and the description of the accidents, and the description of the 
employee's duties in the report gives strong indications when a mining accident is being reported. 2 The annual Eeport of the Kentucky Department of Industrial Felations for the Fiscal Year 1946-47 shows that 36.3\% of all accidents reported during the year were mining accidents. Since the 125 cases constituted $36.7 \%$ of the sample, it is indicated trat this questionable method of distinguishing mining cases at least reets the test of proportionality.

An examiation of the cases in the sample shows that in 55 c.ases trere was no information given on the marital status of the employee. Of the remainIng 284, sone 245, or $86.3 \%$, were married and only 39 , or $13.7 \%$ were unnarried. Thus in almost seven out of every eight cases the worker had legal dependents. The figure of 245 married workers includes seven who were listed as "widowed".

An effort was made to discover from the 339 files examined the number of chilchen the injured employee had. A di ficulty was encountered on this point. Only the report form used by the mining companies contatis a space to show the number of

2. Such accidents as being injured by slate falling from the roof are typical only of a mine. 
dependent children the injurea had in addition to his wife. Among the 125 mining cases, a total of 69 workers were listed as having a total of 233 children for an average of 3.8 child en each. The 69 cases include some married men definitely listed as having no children. In the other cases of married viners the space for number of children was left blank and trey were not included in the average. Since the minling industry is locrlized in only certain areas of the state, wich possibly have their own cultural patterns as far as size of family is concerned, it is felt that these figures on the number of defendents shoula not be applied to all of the industries of the state.

An analysis was also made of the wages earned by the workers involved in these accidents incluaed in the sample.

In only 329 of the cases was it posible to determine the exact weekly wage of the employee. In the other cases there was merely a notation of "maximum" wage. The average mage of the 329 workers was $\$ 46.79$. In only 51 cases was the employee making a lesser sum than that required to give the maximum benefit payment of $\$ 18.00$, $\$ 15.00$ or $\$ 12.00$ a week depending upon the type of injury. This constitutes 
$15.0 \%$ of the employees involved in the sample. Only one of these 51 low-paid worlzers recelved a pemanent partial injury, and the other 50 received total temporary injuries. This means that in $98.2 \%$ of the permanent partial injuries and in $82.3 \%$ of the total temporary injurtes, the worker received benefits at a rate less than $65 \%$ of his wage.

The cases were divided as to tine type of injury and it was found that in the 273 total temporary cases where definite wages were known the average wage was $\$ 40.00$. However, due to the 18.00 ceilling on weekly benefith ig equal ty $38.1 \%$ of the average wage and $43.4 \%$ of the median wage for the total temporary category. These figures do not take into consideration the waiting period of seven days immediately after the injury during which no benefit is paid unless the total disability excesds four weeks. In 188 of these total temporary cases less than four weeks were missed from work and benefits were not paid retroactively for these seven days. Nost of the disabilities involvea in the sample were from relatively unimportant injuries. The average benefit payment in the total temporary 
cases was $\$ 60.49$, covering payment for 24.5 days of compensable injury. The median disability payment was much lower, $\$ 33.42$ for 13.5 days. The average period of total absence from work was 28.8 days and the median was 20.5 days. Thus by including the waiting period the average wage missed by the worker for a period of disablement was $\$ 192.47$ and this was partially compensated by an average benefit payment of $\$ 60.49$. Thus the average wage loss was $\mathbb{W}_{13} 131.98$ per total temporary injury, and benefits amounted to but $31.6 \%$ of lost wages when the waiting period is incluaed.

A breakdown of the number of weeks benefit paid in total temporary cases is given in Table I and a numerical distribution of the wages earned by these employees is given in Table II. The infomation in these two tables is the basis for Chart $I$, and Chart III, shows the distrihution of wares in permoneit portjal cases.

Chart I. shows that the wage distribution is bimodal, reaching one peak in the $\$ 30.00$ to $\$ 40.00$ a week range and a lesser peak in the $\$ 00.00$ to $\$ 70.00$ a week range. This is probably affected by the sharp differentials in pay between unskilled and skilled labor. It was not possible to separate the cases on the basis 
of the skill of the worler in order to verify this assumption.

Any analysis of the permanent partial injury cases in the sample is made difficult by the fact that benefits vary according to the extent of the permanent injury rather than accoraing to the length of tine time the employee misses from work. Frequently the worker continues on the same job at the same pay after the healing period is over. It is not possible to predict the extent to which the permanent impaiment may at some time in the future affect his chances of maintaining a job or obtaining advancenent. Thus in permanent partial cases it is much more difflcult to find some standard to use in measuring the 
adequacy of the payments received. ${ }^{3}$

3. The difficulty of establishing any pattern for considering permanent partial injuries is illustrated by the wide variations in the natur of the injuries received. Infornation was obtained on the nature of the injury and the portion of the body injured. The greatest number of injuries falling in any one classification was found to be contusions and abrasions which amounted to $19.7 \%$ of the cases in the sample. This was followed by $18.6 \%$ listed as lacerations; 15.6\%, sprains; $14.7 \%$, fractures; $9.1 \%$, unclassified; $7.6 \%$, mashed or crushed; $6.5 \%$, cuts; and $3.8 \%$, burns. From this 1 t can be seen that the more prevalent injuries are contusions, lacerations and sprains, 211 of which are generallyminor in nature, and in conformance with the large number of total temporary cases found. When injuries were considered from the standpoint of the parts of the body affected, it was found that the most commonly occurring injury was one involving one or two phalanges of one finger; this occurred in 58 cases, and was followed next by 39 injuries to the entir hana and by 32 injuries to one foot; 31 , to one leg, and 24 to the back. The overall pictures of the injuries shows that in the sample there were 139, or $41.0 \%$ injuries to a ha: or arm; 100 , or $29.5 \%$ injuries to the leg or foot, and 100, or 29.5\%, injuries to the rest of tre body. 


\section{CHART 1. \\ WAGE DISTRIBUTION IN \\ TOTAL TEMPORARY CASES IN SAMPLE}

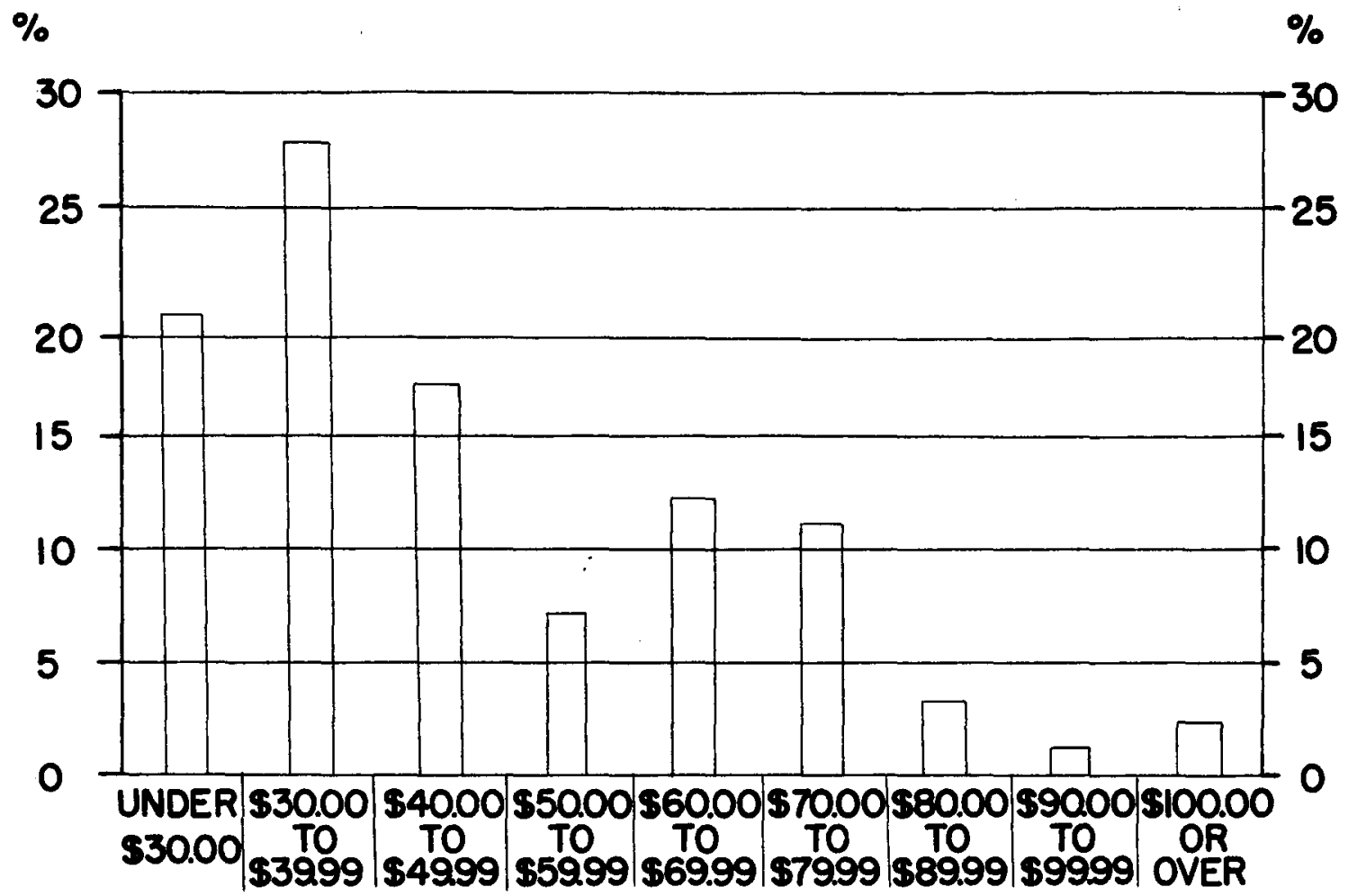

CHART 2.

WAGE DISTRIBUTION IN

PERMANENT PARTIAL CASES IN SAMPLE

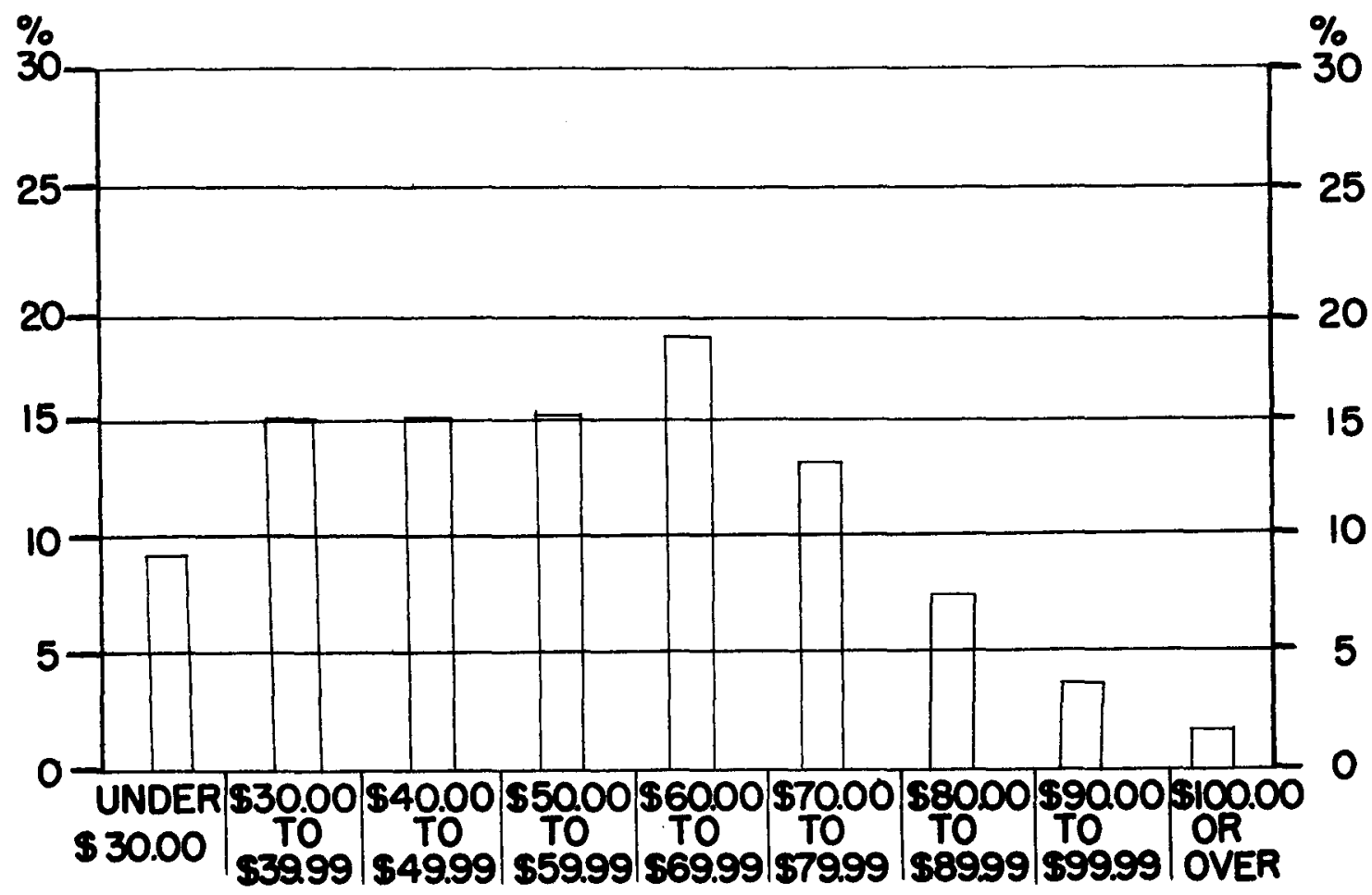


EIST IBUICN CF BEWEITS PAII ACCORDIEG

IO IFE SIZE OF TIA PAY EIT IN TORAL

THIRPOAHY DISABILITY CASES IN SAMPIE

\begin{tabular}{|c|c|c|c|}
\hline TOTAI & EENEFIT & $\begin{array}{l}\text { APPFOXIJATE HO. } \\
\text { WEOKS DISAEIIIII }\end{array}$ & MUNEEI \\
\hline 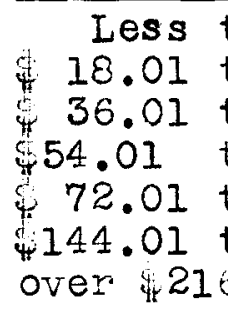 & $\begin{array}{l}\text { than } \$ 18.00 \\
\text { to } 36.00 \\
\text { to } 54.00 \\
\text { to } \$ 72.00 \\
\text { to } 144.00 \\
\text { to } 216.00 \\
6.00\end{array}$ & $\begin{array}{l}1 / 7 \text { to } 1 \text { week } \\
1-1 / 7 \text { to } 2 \\
2-1 / 7 \text { weeks } \\
3-1 / 7 \text { to } 3 \text { weeks } \\
4-1 / 7 \text { to } 8 \text { weeks } \\
8-1 / 7 \text { to } 12 \text { weeks } \\
\text { ovier } 12 \text { weeks }\end{array}$ & $\begin{array}{r}98 \\
61 \\
32 \\
4 \\
60 \\
20 \\
6\end{array}$ \\
\hline
\end{tabular}

TABLE II

DISTKIBUTION OF WAGES EATHED EY WOKKER IN TOTAL TEIFOHAY

DISABILITY CASES IT THE SAIPLE

\begin{tabular}{|c|c|c|c|}
\hline WEEKLY WAGE & WUNBEF & $\%$ OF 273 & $\begin{array}{l}\text { IRELATION OF } \\
\$ 18 \text { TO WAGE }\end{array}$ \\
\hline 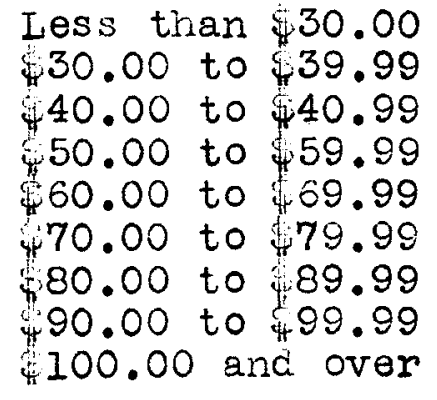 & $\begin{array}{r}56 \\
78 \\
45 \\
21 \\
32 \\
29 \\
9 \\
3 \\
5\end{array}$ & $\begin{array}{l}20.1 \% \\
28.1 \\
16.2 \\
7.6 \\
11.5 \\
10.4 \\
3.2 \\
1.1 \\
1.8\end{array}$ & $\begin{array}{r}65 \% \text { to } 60 \% \\
50 \% \text { to } 45 \% \\
45 \% \text { to } 36 \% \\
36 \% \text { to } 30 \% \\
30 \% \text { to } 25.7 \% \\
25.7 \text { to } 22.5 \% \\
22.5 \text { to } 20.0 \% \\
20 \% \text { to } 18.0 \% \\
18 \% \text { or } 18.5\end{array}$ \\
\hline
\end{tabular}




\section{PABTF III}

\section{DISTRIBUTION OF WACES EARNED BY ORER \\ IN PERMATMNT EARTIAL DISABILITY \\ ChSTS IN THE SHPIE}

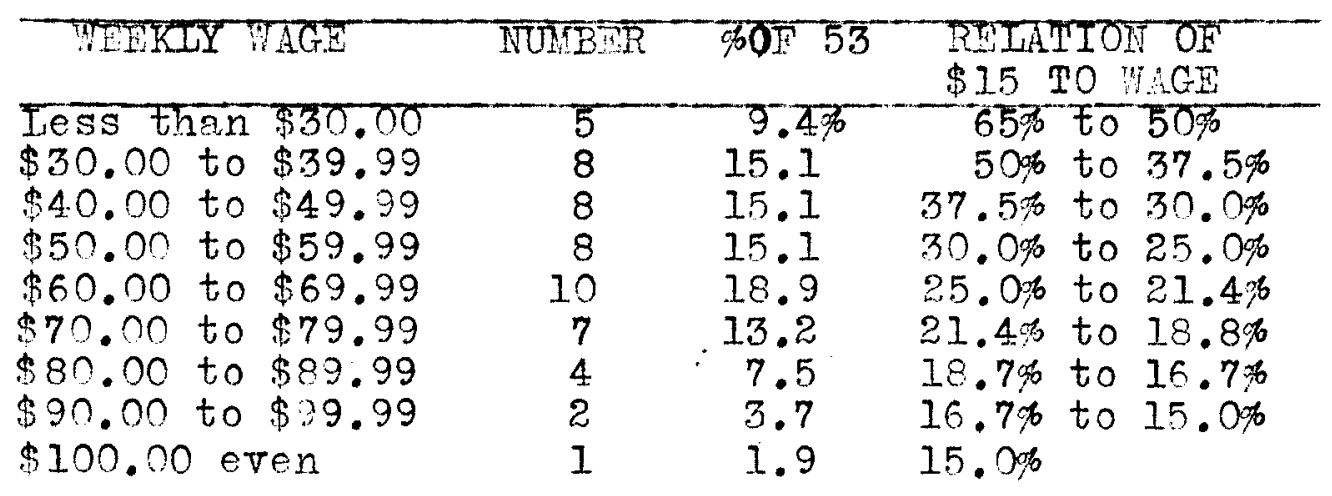


In only 53 of the permanent partial cases was it possible to tell exactly the wage of the employee. The average weekly wage was $\$ 55.43$ and the median wage was 58.00 a week. The fact that the median was larger than the average indicates that the body of the injuries fell among the higher paid workers. This bears out the figures previously given on the high incidence of permanent partial injuries in the coal mines where the pay is generally high, due to the hazards of the iork and the success of collective bargaining in the industry.

A numerical distribution of the wages in permanent partial cases is shown in Table III and curve of the distribution is shown in Chart II. It shows that in these cases there is not a bimodal curve, but that the curve rises only to a flat plateau from $\$ 30.00$ to $\$ 60.00$ and then rises to a brief peak in the $\$ 60.00$ to $\$ 70.00$ a week range and then falls sharply. If the same analysis of the differential between unskilled and skilled labor be used again, it would indicate a much higher incidence of permanent partial injuries among skilled laborers than was found among the total temporary cases and the converse that there 
were relatively fewor permanent partial accidents among the slilled workers. Of course, it must be recognized that seniority on a job tends to give higher pay, but there should be a definite relationship between seniority and skill in most cases. There was only one instance among the 53 permanent partial cases where the weekly wage was less than the $\$ 23.08$ which entitles the worker to the maximum of $\$ 15.00$ for a schedule injury. The duration of the paynents received depend on the part of the bociy impaired, in both schedule anci non-schedule cases. However, the size of the weekly payment depends on the percentage of impairment ratier than on whether tine was being missea from work. Thus once the healing period was over and the man returned to ork he either received a Iump sum paynent of the remaining money due or else continued to get rogular payments after he returned to work. Thus he was at least for a period in an improved financial situation in many cases. In only three permanent partial cases was a rating or more than $50 \%$ aisability to the body as a whole given; also in ono 
case tinere" ân amputation of an arm and in another a rating of 70\% disability to a leg. In these few cases the file was not clear as to wether they were able to return to their former jobs, but the nature of the injury made it questionable. In the remaining 50 permanent partial cases it was indicated that the employee returned to his saile job. Since in all of tae total temporary cases, except one, the employee returned to the old job, it is incicated that there was no difficulty witr remployment in $98 \%$ of the cases in the entire sanple.

After the employee had returned to work, there was a strong tendency to pay him the remainirg compensation aue him in a lump sum rather than weekly for the specified period. In 19 cases lump sum payments were mace after tre healing period. This constituted $34.5 \%$ of the permanent partial cases in the sample. In 40 of the 55 remarent partial cases the file shows that the employ was paic at the rate of $\$ 18.00$, or sligt ty less, during the nealing period. However, the number of weeks that the benefit was paid at the hicher rate was later subtracted from the total number of weeks for which he was entitled to rayments 
at the schedule or non-schedule rate. This accounts for the fact that the length of the healing period was given in the file. Thus if there were a three week healing period followed by a $11 \%$ disability to one eye, the three weeks would be deducted from the one-hundred weeks period of pament authorized in the schedule for this injury, and the worker woulc be entitled to receive ninety-seven weeks compensation at the rate of $\$ 1.65$ ( $12 \%$ of $\% 15.00$ ). An average of the healing periods in the 40 cases in the sample was 16-3/7 weeks, and the medien was $8-5 / 7$ weeks. Only nine of these healing periods, or $22.5 \%$, ran in excess of 20 weeks. Under the 1948 amendmert, only the excess over 20 weeks is now deducted.

As a parallel to the above figures on healing periods a check was made of the 936 permantent partial cases abstracted from tine register. In 511 of these the healing period was given. The average Ior this grouk was a healing period of $16-5 / 7$, as compared to the average of $16-3 / 7$ weeks in the sample. However, the median was $11-1 / 7$ which is considerably higiner than the median of $8-5 / 7$ weeks in the sample, and there were 144 cases, or $28.2 \%$, where the healing perioo was in excess of 20 weeks. 
It was feit that the three death cases in the sample were too $f \in w$ to give an accurate picture for this type of case. In only 77 of the 85 death cases abstracted from the Register was it possible to tell the average weekly wage. In the remaining cases it was only indicated that the wage was high enough to entitle the dependents to the maximum benefits.

The average wage in the 77 cases was $\$ 59.11$ and the median wage was $\$ 60.20$. Once again the median ran higher than the average and both figures show that the deaths occurred more prevalently among the higher paid workers. Thus as with the figures on the pemanent partial injuries there appears to be a correlation between the hazards of the job and the size of the wage paid.

The Register showed that in six of these cases only an even fraction, such as $\frac{1}{2}$ or $\frac{1}{4}$, of $\$ 15.00$ was paid indicating that only a relation of partial dependency was established by some relative. In only 2 of the remaining 79 cases was the worker's wage so low that less than the weekly maximum was payable. The average weekly benefit in these 70 cases was $\$ 14.93$ for full dependents. If the cases of partial cependents be added, the average payment was $\$ 14.54$ a weck. These low benefit rates occur among the families which have 


\section{CHART 3 \\ WAGE DISTRIBUTION OF \\ FATAL CASES}

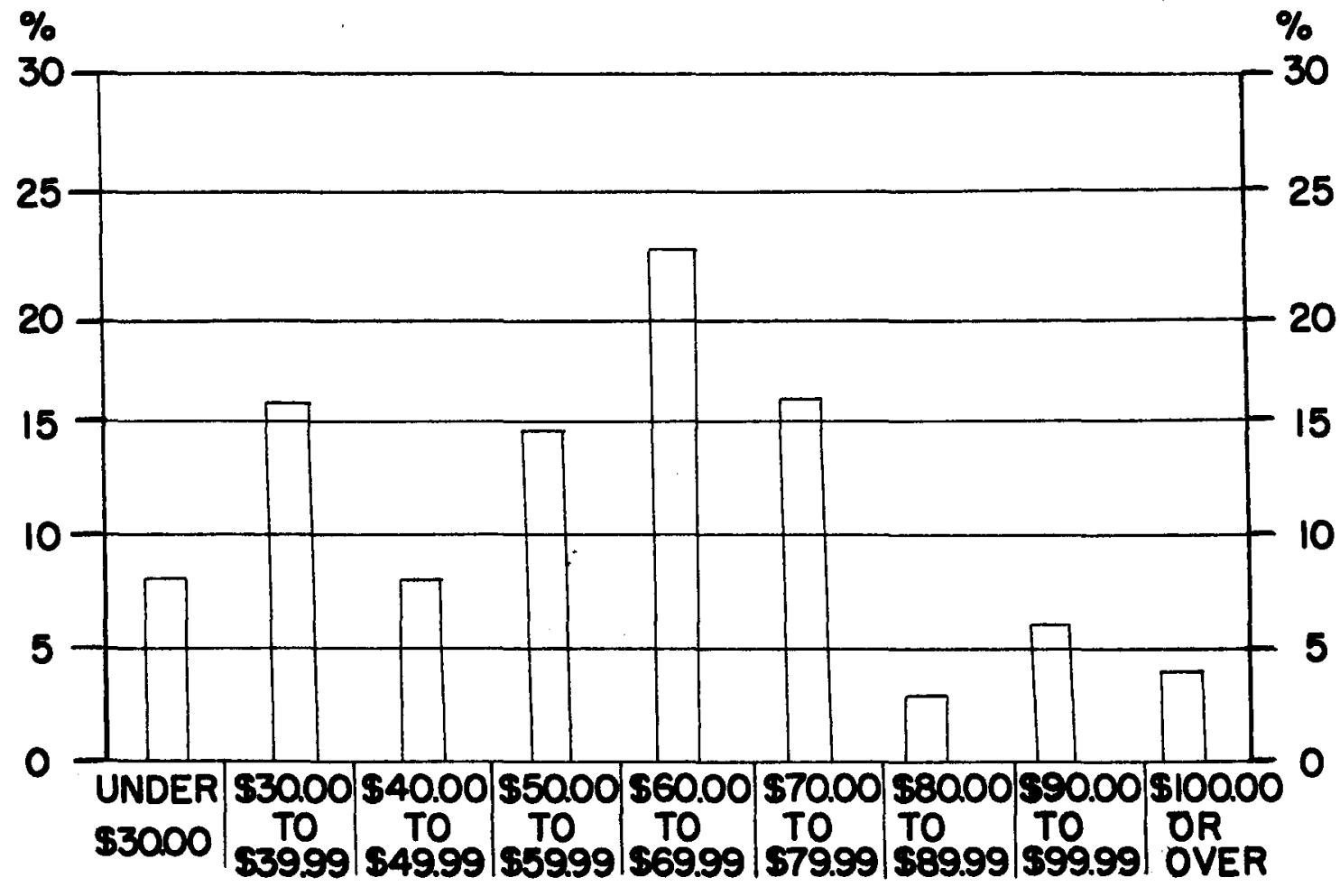


been accustored to receive the hichest average incomes. In the 79 cases where it is known that the employee is survived by one or more persons who were legally established as fully dependent, the average weelly benefit of 14.93 constituted but $25.3 \%$ of the previous weekly income of the employee. It is trme that the dependents in most cases can depend ufon receipt of this income for a known period of 400 weeks. This information gives an incomplete picture of the dependency relationships. If time had permitted, and examination of these 85 derth clain files would have shown the number and age of the dependents. However, only actual contact wit the heirs would reveal what aditional sources of income the family hac available through insurance and savirgs. In order to better gauge the value of these weekly benefit payments in terms of real earning it is sugcested trat a brief review be made of the economic conditions in the nation durine tis period from June to December 1946.

$$
\text { By June } 1946 \text { the poet-war reconversion had }
$$
largely been accomplished and full employment levels prevailed. Employ.ent was stable but wage rates 
increased at the rate of $1 \%$ a month. Although wages rose, the situation was entirely aifferent in regard to real earnings. In June 1946 the general decontrol of prices began and during the period from June to December 1946 the Bureau of Labor Statistics consumers price index rose 15\%, the steepest rise for such a period in the 34-year history of the index. The wage gains during the period were more than wiped out by the rising prices. There was a fall of real earnings of $11.6 \%$ among bituminous coal miners during this period.4

An effort was also made to find some index of the cost of livine during the last half of 1846 to use as a conparison with the benefit payments received. No one index was found which was entirely saticfactory for this purpose.

A City Worker's Family Budget was prepared for 1946 by the U.S. Department of Labor. 5 This buaget was developed to show the needs of a family of four living in a city. It is neither a "subsistence" budget, nor is it a "luxury" budget, but is an

4. Monthly Labor Feview, June 1947, pp. 993-96. 5. U.S. Eureau of Labor Statistics, Eulletin 927 , (jarch 1948). 
attempt to describe and measure a modest but adequate standard of living; "It represents what men commonly expect to enjoy, feel that they have lost status and are experiencine privation if they can not enjoy, and what they insist upon having". This buaget is also described as a level "below which deficiencies exist in ore or more aspect of a family concumption." 6 A separate buaget was prepared for each of 34 cities for both liarch, 1946 and for June 1947. No city in Kentucly was included. The median of these bucgets was found in the two budgets for Bimingham, Alabama. In June 1946 the Birmingham budget was $\$ 2521.00$ for goods and services only, anà if sucl items as taxes insurance and occupational expenses be adcied, it rose to 2781.00 . For the period of June 1947 the Bimingham budget had risen to $\$ 2904.00$ and $\$ 3251.00$ respectively. ${ }^{7}$ When the lowest of these figures, that of the cost of coods and services alone for June 1946 is trans lated into weelly wages it amounts to a needed wage of $\$ 48.48$. The weely wage for all the cases in the randon sample used in this study averaged 446.79 , which indicates trat even without an injury the Kentucky

6. Ibid, p. 7 .

7. U.S. Bureau of Labor Statistics, Bulletin 927, (1948), p. 22. 
worker involved dic not quite measure up to tre earnings indicated for tis City Horker's Family Budget.

A different standard can be obtained fron the 1946 Kentucky cost-of-living budget for single working romen. In many states the minimum wage rates are set by administrative action based upon the cost of living. Such buagets are designed primarily to show the annual income necessary to rairtain a self supporting woman in health. This hypothetical single woman worker has no dependents and lives in a boarding house and eats in a restaurant. The budget for Kentucky was designed to show her minimum needs to live adequately in tems of contemporary ideas ana practices. It was based upor a survey made in liarchApril 1946. The results showed that $\$ 1340.97$ a year was needed for commodities and services and that 1562.22 a year was needed if such items as private insurance and savings (\$22.39) and taxes (\$178.65) be aaded. ${ }^{8}$ This last figure amounts to 30.04 a week. The Kentucky survey showed the living costs for a single woman, but a similar survey in las achusetts in 1946 for both men and women reported in the same article shows a striking similarity for it lists 1363.38 for 8. Ibid, pp. 52.54. 
commodities and Services. It did not list the cost of Insurance, savings and taxes. The smaller Kentuclry budget amounted to a weeliy wage of 425.79 , however, this is an unrealistic figure sirce tre worker has no choice concerning the payment of taxes.

Shortly after the budget was prepared, the Hinimum Wage in KentuckJ was raised to $50 \not$ an hour for women, with a $f \in W$ exceptions for waitresses and laundry workers. This amounts to $\$ 24.00$ a week for a 48 hour week. The increase in the minimum wage was not made until hay 1947, however, it appears to be based upon the cost of subsistence for a sirgle woman during 1946.

When the average benefit payment of $\$ 17.35$ for total temporary injuries is compared to these three standaras, it amounts to $35.8 \%$ of the city family budget, $57.8 \%$ of the working woman's budget, and $72.3 \%$ of the present minimum wage for women.

Then these figures are compared with the \$14.87 average berefit for a schedule permanent partial injury, it constitutes $30.7 \%$ of the city family budget, $49.5 \%$ of the single woman's budget and $61.9 \%$ of the minimum wage for women. When they are compared 
with the 12.00 maximum paynent in non-schedule permanent partial cases, it amounts to $24.9 \%, 39.9 \%$ and $50 \%$ respectively.

When the average benefit of 414.93 a week, which was paia to full dependents of deceased employees, is compared with these standards, it constitutes $30.8 \%$ of the city family budget, $49.4 \%$ of the single woman's budget, and $62.2 \%$ of the minimum wage for women. Admittedly the city workers family buaget is open to many criticisms as a standard for judging the adequacy of benefit paynents made under the act. First of all it is designed for a family of four, a husband, a wife who does not work and two chilaren of school age. Among the coal miners the family size was larger than this, but there are bound to be many families affected by tre Act which are not this large. Furthermore only a portion of the workers involved are city dwellers. Also the budget is not designed as a subsistence budget, but as a budget ainec at the poirt at which the family stops worrying about being able to buy more items for the family and begin to becone concerned with buying 1tens of better quality. probably the best way to consider this budget is as the 
very upfer limit which should enter into any discussion of the adequacy of benefit peyments.

These criticisms can not be made of the \$24.00 mininum wage for women. Due to the fact that none of the files involving injury to women showed the number of their dependents it is impossible to tell how many women without dependents were irvolved in injuries. Of the entire sample, only $8 \%$ of the injuries were to women and only a portion of these were single and free of defendents. For these few women the very highest scale of 18.00 a week was only $72.3 \%$ of this minimum amount needed for health anc decency. However, most injured workers have more financial responsibilities than coes the s:ngle wonan. Therefore for a large majority of the irjured workers in total temporary accidents, the adequacy of the benefit ranges somewhe downward from a high of $72.3 \%$ towara a minimuri low of $35.8 \%$. In trying to evaluate the adequacy of the benefits paic in peranent partial injuries, the extent of the impairment interjects an aditional variable which makes it doubly difficult to gauge. 
Amone the fatal cases tre $\$ 15.00$ a week amounts to $62.2 \%$ of tie minimum wage for single wonen. In cases of wiow without children and able to work the benefit pament is excellent as a supflement to her wages, but it is questionable whether it is enough for her to live on without having to go to work. This is the optimum situation for dependents. In the case where a widow is left with several children of school age, the adequacy of the benefit is far below $62.2 \%$. Should the wife go to work it is necessary for relatives to assure a share of caring for the children or else trie wiỏow must hire someone to care for them or place them in an institutions. Under the Kentucky Aid to Dependert Children program additional aid would have been possible for the widow. This program would, in 1946, supply 50\% of the deficit in the family budget up to a maximum payment of $\$ 18.00$ a month for the first child and $\$ 12.00$ a month for each additional child under the age of 18 years. The only governmental allowace possible to the widow herself is the social security allowance in cases were the widow is older thar 65 jears. 9

9. Interview, Lr. Grubbs, State Office of Économic Security, April, 1949 
CHAPTLE 5 


\section{CHAPILER 5}

THE ADWIIISTRATIO OF THE KUITUCKY

WOEKLEN'S COLPEINSATIG: ACT

"The ends sought in the administration of a compensation law are the prompt and full payment of uncontested claims and the cheap and equitable determination of disputes". 1

Both the National Conference of Labor

Legislators and the I. A. I. A. B. C. have recommended that a commission or board be used rather than the courts in order to secure a simple, convenient and inexpensive method of setting the claims of injured workers. 2

The Kentucky legislature has set up a Workmen's Compensation Board as a part of the Departinent of Industrial Relations. It consists of three members aprolnted by the Governor, and an executive secretary for the Board is apfointed $b$ the commissioner of Industrial Relations. 3 The executive secretary has immediate supervision of the employees of the Board. Wach employer operating uncer the workmen's Compensation Act is required to report witin seven days after knomlodge thereof every injury causing an

1. Downey, Op Cit, p. 60.

2. Monthly Labor teview, October 1846, p. 547. 3. $\overline{K R S ~ 342.215,342.220 .}$ 
absence from work of more than one day. 4 The employer is subject to a maximum fine of $\$ 25.00$ should he fail to file this report along with a suplemental report when the employee returns to work. ${ }^{5}$ when the customary procedure is followed the employer and the employee enter into and sign an agreenent as to the amount of compensation due the employee under the Act. Iwo different forms are autiorized by the Board for this purpose. One is a preliminary agreement in which the facts of the accident and the injury are set forth and the weokly rate at which the employee is to be paid is stated; this is designed to be agreed upon at the beginning of the disablement and it is generally referred to as an open agreement since it sets no final limit on the benefits which will become due. The other form is a final agreement form to be signed after the worker has returned to rork or after permanent degree of disability has been determined; it sets forth the final curation of disability and states what total benefits are due the employee. However, there is othing in the law requiring the employer to file either of these two agreenent forms with the

4. $\operatorname{KrES} 342.330$

5. KES 342.990 (1). 
Board. Once an injury is reported to the Board a file number is as signed to 1 t, but no case is ever closed until a final agreoment is filed mith the Board and aproved by it. The failure to flie this agrement is the cause of so many cases still being open with the Board.

In cases where the employer and the emflojee can not reach an agrement as to how much compensation is due the employee, he may request the Board for a decision on the merlts of the case. The case is then assigned to a referee for a hearing of the evidence. The referee reports his finding and these are turned over to one of the Board members for a decision. Ether side may request a review of the decision of the single member by the full Board. Decisions of the full Board are final regarding the determination of the facts in the case. However further apreals can be made to the courts for interpretations of the points of law involved. Apfeals from the Board are made to the circuit court and may be further appealed to the court of Appeals. Disputes arise in only a small percentage of the cases. In the others it is the purpose of 
the law that the parties arrive at an agreenent between themselves based upon the provisions of the Act. If the agreements are filed with the Board, it passes upon them and if everything apreas to be in accordance with the provisions of the law, the Board ordinarily aproves the final agreemert and closes its file. iven though a file has been closed it may always be reopened by the Board upon the submission of proof that the final agreenent was obtained through fraud or that trere has been a subsequent change in the physical condition of the employee as a result of the injury.

Such a system as this puts the emprasis on direct handing between the employee and the employer, or the latter's insurance company. The employee, if not satisfled, by such direct contact, may always call upon the Board for a decision. As noted elsewhere, the randon sample used In this study was obtained by taking every tenth file number from among 7000 reported to the Board during the last half of 1946 . Of the 700 cases so chosen, 49 were of injuries occurring either before or after tie six months period being surveyed. Of 
the remaining 651 cases, 312 , or $47.6 \%$ consisted only of an accident report and nothing else. They were still being carricd as open files. In these cases the Eoard had no information as to the duration or extent of the injury other than what had been furnished by the employer in his accident report. There was nothing in the file bearing the signature of the emploree to verify that an agreement had been reached or that any benefits had been paid. It is posible that all of these were cases where the employee missed les : than seven days from work and had no permanent injury, and thus no benefits were payable to the worker. However, the fact remains that these files are so incomplete that the Board is unable to determine this to be the case and it is not within the power of the Board to require the filing of final agreements.

A detailed check was made of each of the remaining 339 files in which more complete information had been filed with the Board. The nethods used in checking the reliabilitj and validity of this sample are outlined in Appendis A.

One of the goals of prompt aciministration 
is to see that benefits are paid promptly and regularly. Wany records were incomplete and in only 275 of the cases was it possible to determine the date on which the first payment was made. It was founc that this occurred on an average of 47.3 days after disability began. In the ordinary case the first payment of weekly benefit is not due until tie 14th. day after disability. began. A certain amount of investigation is required on the part of the employer to detemine if the claim is one which properly shoulá be paic, and therefore some delay in making the first pajment may be expected, but once payments start there is no reas on why they should not be made at regular intervals thereafter.

A breakdown of the tyces of cases shows that among the 232 total temporary cases tiere was an average delay of 45.0 days from the date disability began until the first payment was made. Among the three fatal cases there was an average delay of 41.3 days and among the 40 cases of permanent partial disability the average delay was 61.1 days. It should be noted that in this last subdivision there are included two cases in which petitions 
were filed and fearings held before any payment was made. If these two cases, where part of t e delay was due to the administrative procedures of the Boara, be elinirated, the averag for the remaining pemanent partial cases was 36.9 days and the average for the entire a oup of 273 cases is 43.8 cays.

The above figures cover only the speed with which the first payment was rade. The regularity of subsequent payments is also a matter of interest. Out of' the 275 cases, a check shomed that there were 44 cases, or $26.9 \%$, In which origial paynets were made within 28 days and in which there were subsequent payments which were made in a prompt and regular mamer. In these cases the original paynert wa made on an average of 20.6 days after disability began and the remaini 8 paynents were made at regular intervals of one, two, or four weels. In 188 cases were no claim was filed with the Eoara, there was only one payment made and this was made at the time of the final settlevent with the worker. ihese payments were made on an average of 50.2 days after the start of disability. However, an analysis of these 188 cases where only one payment was made 
showed that in 136 cases, or $49.5 \%$ of the 275 known cases, they miswed no more than 28 days fron work, and the one pajment was made on an average of 38.5 days from the disability date. The procedure of not making intermediate paments on a perioa of short disability can pos ibly be justifiea from an adrinistrative standpoint, but it is rard to justify the delay of 38.6 days from disability in these cases.

In the remaining cases, which constituted $23.6 \%$ of the 275 , no paynent was made until the firal settlement. In each of these there was a disability of more than 28 days and in nore of them was toere any litigation. Amo these there was an average delay of 80.9 dajs in making the one paynent. If the two cases be adoed in wich a hearing mas held by the Board before any payment was made, the delay in making the one pament rises from 80.9 days to 97.3 days.

In the remaining 11 cases more than one payment was made but the payments were inade at very irregular Intervals. These constituted $4 \%$ of the 275 knom cases.

To sumarize the speed wit wich the 
infial payment was made, it is indicated that in $26.9 \%$ of the cases pajments were made p.omptly and regularly; that in $23.6 \%$ of the cases there was a long aelay in maline payments of compensation for periods of disability in excess of 28 days; and that in the remaining $49.5 \%$ of the cases there was a single payment for les tran 28days disability, but that this one payment was made after a questionable delay.

Another point of interest is the speed with which a final settlorent was made with the worker. In only 294 of the cases in the sample was it posaible to determine the exact d te on which a final settlement was made. In the remaining cases the final arreerlent form was not duted or else a permanent injury was involved nd the agreement was signed before tice worker returned to work.

In the three cases involving a death the agrements were signed on an average of $3 \ddot{.} 3$ days after the date of death and 41.3 days after the date of the injury.

Among the 291 other cases in which the date of settlement is known, there was an average lapse of 
76.7 days from the date of injury. However, it must be remerbered that in most cases it is not possible to prepare tise final agreenent for signature before the return of the employee to wonk. A check of these 291 cases shoms that there was an average disability of 38.4 days and that the settlement was reached on an average of 38.3 days after the return of the emplojee to his job.

A breakdown of tis is figure between the total temporary injuries and the permanent partial injuries showed a marked variation. Among the 255 cases involving total temporary injuries trere was an average delay of 23.2 days from the return of the worker to his job until the signine of the agreement. However, with the 36 pemacent partial cases there was a delay of 145.5 days. The median celay of thie group was 130.5 days.

There are several pactors wich te do cause a delay in making a final settlenent in a permanent fartial case. It is in this type of case that there is greater room for disagreenent as to the extent of the injury. All four of the cases in which petitions were filed and hea ines relà by a 
referee are found in this group. Another factor is that in uch cases the nealing 1 slow. In these 36 cases there was an average period of 95.3 days before the worker could return to work. It is piobable that in some of these cases the worker retumed only to light work ano it was not until later trat the attunding doctor felt that a maximum recovery nad been obtained and was willine to ve ture a rating of the percentage of renaining disability. In such cases it is to the advartage of tie employer to wait for maximum ecovery before obtaining a final ratine of the percentage of permanent partial disability which is left from an injury. Since the worker has returned to his job and is again on the payroll he does not aply as much pressure for a final agreemert concerning the extent of permanent injury. This may in part account for the delay of 118.4 days in entering into final settlements in the cases where there was no litigation.

A more detailed check was made of the administrative handling of 55 permanent partial injuries. In 11 of these cases payments were made at regular intervals, at the permanent partial rate of 
\$15.00 \& week, for the period of time for which payments were due or else payments were still being made at the tirne the file was examined. In these 11 cases it was not always clear whether the worker had missed any time from work. For instance the worker might suffer the amputation of a little finger and return to work within seven days. In this case he would still be entitled to payments of 415.00 a week for 15 weeks even though he was not absent from work for 15 weeks.

In the four perianent partial cases where a petition was filed for a hearing by the Board, an average of 523 days, or 17 months, 6 days elapsed from the date of the disability until final paynent. In two of the cases a compromise was reached and in the other two a Board decision settled the case. When the healing perioa is subtracted in these cases it is found that final payment was made on an average of 362 days after the return to rork.

In three of the permanent partial cases the file was so indefinite that it was imposible to tell what was paid or when.

In one of the permanent partial cases 
rather peculiar circunstances were involved. The employee had arthritis of tre spine prior to receiving a back injury which left him totally and permanently aisabled. After drawing kenefits at the rate of 18.00 a week for 49 weels, he entered into an arreement stating that he was totally aisabled but that $60 \%$ of the disability was due to a pre-existing condition and agreed to accept $\$ 4.80$ a week (40\% of 15.00$)$ for 371 weeks (420 weeks les the 49 weeks already paid). This agreement was approvea by the Board and the file closed. The employee later enployed an attorney but the Board fialled to reopen the case on the grounds that no medical proof was submitted that the nan was less than $60 \%$ aisabled prior to the accident. The attorney made no apparent effort to secure a payment from the Subsequent Injury Fund mentioned previously.

In the remaing 36 permanent partial cases the employee was paid total temporar'y benefit, at the rate of $\$ 18.00$ a week, during the period of recovery from tine injury and was paid the remaining benefit due him for the pernanent injury in a unit payment after his return to work. In the cases 
where there was a lengthy healing feriod followed by some jemanent partial injury, there seemed to be consioerable confusion among the employers as to whether the worker should be paic at the rate of 18.00 or 15.00 a week during the healing period. The 1946 law was ambiguous on this point, but this has been cleared up by the 1948 amendment with regard to the healing period.

The examination of the files showed that there was considerable uniformity in the speed of reporting injuries to the Board. In all the cases in the sample, the employers report was received by the Board on an average of 32.7 days after the disability began. When this was subdivided according to the type of injury, the elapsed times were 32.8 days for total temporary cases, 32.5 dajs for the permanent partial cases, and 41.3 dajs for the three fatal cases. There was nothing in the files to indicate that any effort was made to fjre any of the employers for a delay in reporting an accident. Fowever the promptness in filing this one report where a fine was possible might be interpreted as indicating an advantage in having the law on the 
statute books. It is in marked contrast to the failure or slowness on the part of employers in submitting agreement forms and medical reports. The Board has authorized and ill furnist

a form which can be used for the doctor's report on the extent of injury. However only in 173 cases, or 50.7\%, was a report from a phjsician filed with the Board. They were subnitted in $56.4 \%$ of the permanent partial cases and in $49.9 \%$ of the total temporary cases. There were rany instances in which final agreements involving serious injuries were submitted to and aprroved by the Board without any medical information being submitted to the Board. Since there is nothing in the law requiring the submission of such reports the Board has little way of verifying that the settiement entered into is in accordarce with the actual physical condition of the employee. One criticis that can be made of the Act as it now stards is that the Board in so nany cases must rely solely on the facts furnished to it by the interested parties. This places a high degree of faith in the fair-mindedness of all parties concerned. several of the files shomed that the 
Board had returned agreenent forms to be corrected in order to conforn with the provisions of the Act on various points. In many of these the Eoard liad to wite roreatedy to secure the return of the corrected forms. The only sanction the oara has if it is not retumed is to withold its approval of the agreenent, and the signed agreement is not bindirg on the parties until i.t has been so aprroved.

It is imposible to tell just from the examination of the files wether or not the medical attention furnished was of the proper caliber. In only a yery few of the cases was there any incication that the patient was treatea br more tran one doctor. This might be interpreted as inaicatin that the employee was satisfied with the attention furmished ana äla not insist upon being treated by someone else. In most of the files in which a medical report was not submitted, the accicent report showed that the employee was being treated by some specific doctor. The above information was taken from the cases randomly selected as a sample. In these cases the entire file was exained. However further information was obtained from the legister maintained 
by the Workmen's Compensation Board. The Register shows whether a temporary, permanent or fatal injury was involved. A code number shows the nature and location of the injury, such as a cut hand or a sprained back. The nature of the injury is divided into nine classifications such as lacerations, buises, iractures, sprains, etc., and the portions of the body are divided into 91 classifications such as hand, index finger, eye, etc.. The Iregister further shows the employees age, his weekly wage, the curation of the disability, the rate at which weekly benefits were faid, the total amount of the award, the date on which the Board aproved the final agreement, whether or not a portion of the benefit was paid in a lump sum and wether or not a request for a hearing was filea. Thus much valuable information was gained on many cases without the necessity of examining its file.

The Register was examined for the last half of 1946 and the above information abstracted on all the cases involving deaths, pemanent injuries and total temporary injurtes involving a disability of more than 60 days. It is felt that 
this covers some information on all the serious accidents happening during the period of this study. In all, 1375 cases were abstracted from the register. This ircluded 85 fatal cases and 936 cases of permanent partial injury. There were three cases in the register which were coded as beire totsl pemarent injuries, but the amount of the final settlenents aprroved in the cases indicate that thej were actually only fartially disablirg. Amone these cases there were 86 in which the parties had not agreed and a petition for a hearing had been filed by the employee. The number of accidents reported to tre Boarci for the entire fiscal year. of 1946-47 was 19,307 . Therefore it is es timated that approximately $\$ 500$ occurred curing the last half of 1946. Thus it is seen trat trere was litigation in only $0.9 \%$ of the cases. This fact speals well for the effectiveness of the conpensation system as compared with the ola connon law practices.

In 18 of the cases where a claim was filed the cast was dismissed by the Eoard without any money being ararded. In these 18 cases it was 
not pos able to tell what type injury was involved since the line in the Fegister was not completed. In the remaining cases claims were filed in 5 fral cases, in 5 total temporary cases anci in 58 pemanent partial cases. When analyzed this shows that claims were filed in $5.9 \%$ of all the fatal cases, in $6.2 \%$ of all permanent fartial cases ana in $0.06 \%$ of the total temporary cases occur ine in the last half of 1946. It is quite apparent that there is a greater tendency for disagreerent over the compensation cue to occur in the two classifications were the more serious injuries are received. It is hard to say whether the small number of claims filed in total temporary cases shows better handling of these cases or whether it merely indicates that so little morey was involved that the employee had difficulty getting so law er to hande the case ror him. The lawyer representing an employee in a claim is not allowed to charge a fee in excess of $15 \%$ of the first 1,000 recovered and $10 \%$ of any amount in excess of that.

The Kegister shows thet in the contested cases where amards were given there was an average 
elapsed time of 416 days, or 13 montrs, 21 days, from the time of the injury until a final decision was made. This is quite a bit less than the 17 months, 6 days which was the average for the four clain cases included in the sample. In these cases there was an average healing period of 155 days. This would indicate a final decision of the 68 claims in an average of 200.5 days after the return of the emplojee to his job. Once again this is consicerably less than the average of 362 days in the four claim cases in the sample. The information fro: the Kegister does not show the length of time from the date of which aisability began until the claim was filed with the Board. However, the averages taken from the register are based upon all the claims during the six months and it follows that the figures arrived at from the four clain cases in the sample were too narrowly based to be accurate. Contested claims generally fall into two nain clascifications: those which involve medical questions and those involving questions of coverage, alt ough come claims involve both. In the first classification fall the cases where it is clear and 
uncontested trat the injury was one arising out of and received in the course of the employnent, but where the interested parties can not agree on what is the actual degree of pemanent injury resulting from the injury. In these cases the testimony is largely medical. In the other caterory the extent of injury is agreed upor but the point ir iscue is whetrer the accident occurred in such a manner as to bring it witrin the scope and operation of the Act, such as the case of an injury while on the way to work. These cases involve testimony relative to the facts of the occurrence. Since the information used on contested cases was abstracted from the Register, rather than from the files, no information was obtained on the relative number of claims based on medical and coverage questions. An examination of all tie 85 fatal cases in the Fegister shows an elapseo time of 81.2 days from the injury until the agreement that had been entered into with the dependents was aprroved ry the Board. This is in contrast with the average of 41.3 days from injury to the signing of the agreement in the three latal cases found in the sample. 
The larger figure of 81.2 days can be affected by the delay on the part of the employer in subititing the agrement to the board after it was signed. Since tie Board meets but twice a month there is a further delay from the ti...e the Board receives it until the date it is aproved. The examination of the fegister also threw light on the practices with regard to making lump sum payments. Amone the 1375 cases abstracted from the Fegister there were lump sum paynents made in 349 of them. itone were found among the total temporary cases since future payments are never involved in such cases. They were made in 13 fatal cases, of 15.3 of those taken from the Fegister, and in 336 permanent partial cases, of in $37.1 \%$ of the register cases. The average amount of lump sum payment was 1415.00 and $\$ 893.85$ respectively.

None of the three fatal cases in the sample involved a lump sum payment. However, a special check was made of the files of the 13 cases abstracted from the register in which the Board authorized a lump sum payment of varying portions of the amount which would eventually be paici to trie dependents. 
The lump sum amounts authorized varied greatly. The smaliest was for 30.50 and the largest was for \$4061.21. The files showed that the smaller awards were generally to be used by the heirs in paying urgent debts incurred in connection with the funeral or final nedical treatment. In the cases where large lur.p sum payments were permitted by the Board, it was in most cases to be used to buy a home or a business which would help suprort tine dependents. Eefore any sizeable lump sum was authorlzed the Board took comriendable precautions to safeguard the welfare of the derendents by requiring the submission of appraisals of the value of the property and full explanations regarding the uses to which the money was to be put. However, a check of the authorizations of lump sum payments in permanent partial cases showed a aifferent picture. A check of the 55 permanent partial cases in the sample showed that lump suns were given in 21 cases. The file showed that the only thing that was submitted was a completed form signed by the employee requesting that the remaining money due him be paid in a lump surn. 
Only very vague reas ons such as "mutual convenience of the parties" or "to pay debts" were given, In each of these cases the payment was authorized without a requirement of any further verification of the need involved. In no cases among the permanent partial cases in the sample was a request for a lump sum payment refused, or even questioned. Whe distinction. in the handins of the two types of cases is apparently based upon the fact that in the one case the request is being made by a widow, infart children or other dependent relatives, and in the other case it is being made by the injured employee himself.

In each case where a lump sum award is authorizea, the employer is allowed to deduct $5 \%$ compouncied interest on the theory that if the money were held by him he would have it so invested during the time before the various payments were duedthat it would be earning $5 \%$. In the case just mentioned where a Iump sum of 4061.21 was authorized, there was a loss of approximately $\$ 575.00$ to the dependents in the total amount of benefit they received as contrasted with the 
amount trey woula have gotten if the money had been paic in installments over the period of 400 weeks. During the later part of 1946 interest rates in general were 1 ow and it is questionable whether the employer could have invested the money at $5 \%$. Therefore on this as sumption it woula be to the advantage of the employer to encourage requests for lump sum payments.

There has been considerable question among writers on the subject about the advisability of a lurip sum payment in the ordinary case. One study was made several years ago on this subject and its conclusion was that in practically ail of the cases the money was spent ill-advisedly and that there was no long-run aciantage to the recifient in getting the money in advance. ${ }^{6}$ The contested claims are the only ones which normally come to the personal attention of the Board members for any detailea consiaeration. The great mass of uncontested cases are handied by the administrative staff which 1 directly responsible to the full-time 6. Dodd, Op Cit, p. 727, 779?. 
Executive Secretary of the Board. When an accident is reported they record it and open a file on it, As the further papers, such as medical reports, are submitted by the employer they are placed in the proper file. When properly signed preliminary or final agrements are filed, they are checked for accuracy and if found to be in accordance with the provisions of the Act the whole file is submitted to the Board, when it mets twice a month, for approval of the agreement. If the papers submitted show on their face that payment has been at the wrong rate or for an improper interval, the agreements are returned to the employer for conrection before the agreements will be approved and the case closed. The files showed many case: where it was necessary to write the employer many times on the subject before the agre wents were re-submitted in the proper form.

Witrin these boundaries, tre whole administration of the Board functions with speed and efficiency. However, there are other items affecting the employee over which the Board has little 
influence in the uncontested case; in many cases it does not receive adequate physician's reports against wich it can compare the correctness of the provision: of the settlement; it recelves little accounting of what money is spent on medical service or the caliber thereof, and it receives little information concernin the romptness and reaularity of benefit pajyents. In order to achieve these the Workmen's comrensation Act would have to be made more stringent and a larger administrative personnel allotted. The decision whether this is needed and desirable rests solely witr the State Legislature. 
EIBIIOGRAPHY

BOOKS

Bowers, E. L., Is It Safe to Work?, Hought on Mifflin company, (1930).

Brown, L.O., Harketing Research and Analys1s, (N.Y.), 1937.

Dodi, W. F', Administration of Norkmen's Compensation, The commonest Fund, (1936).

Downey, E. H., Workmen's Compensation, The kacmilian Company, (1924).

Eas tman, Crystal, Work Accidents and the Iaw, The Pittsburg survey, (1916).

Henders on, C.E., Industrial Insurance in the United States, University of Chicago Press, (1909).

Horlacher, J. P., The Results of forkmen's compensation in Pennsylvania, Commonwerlth of

vennsylvania Department of Incustry and Labor, (1934).

Horovitz, 3. B., Current Trends in vionmen's Compensation, The Law Society of lissachusetts, $(1947)$.

Kessler, H. H., Accidental Injuries, Columbia University Press, (1932).

Labatt, C. B., Waster and Servant, Lawyers cooperative Publishing Company, (1903).

Fubinow, I. F., Social Insurance, F. Holt and company, (1913). Teblen, T., theory of Business Enterprise, C. Scrib-
ner's Sons, 2nd. Edit., (1932, c 1904).

Wharton, F., Comentaries on the Law of Negligence, Law yers Cooperative Publisting Company, (1905). 


\section{PAIPIILETS}

Annual Feport of the Departinent of Industrial ielations, Commoninealth of Kentucky, Fiscal Year 1946-47.

Kentucky Kevised Statutes (K R S), Chapter 342, Banks-Baldwin Company (1948).

U.S. Bureau of Labor, Bulletin 74, (1908).

, Bulletin 92, (1911).

U.S. Eureau of Labor Statistics, Bulletin 126, (1913).

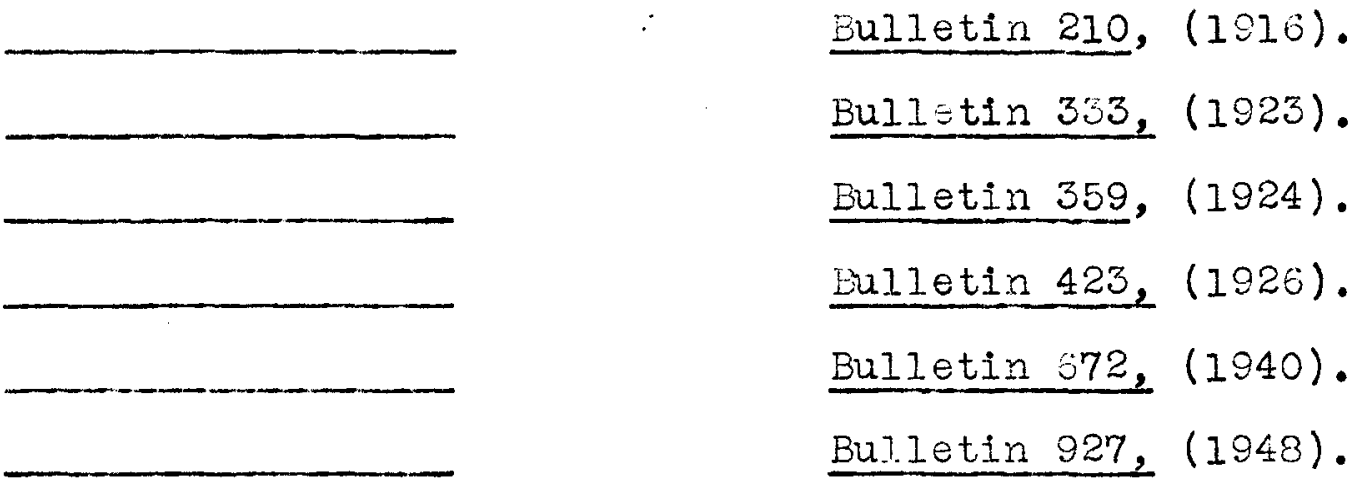

U.S. Eureau of Labor Standards, Bulletin 78, (1948).

PEFI ODICAIS

Iowa Law Keview, Vol 28, (1942)

Monthly Labor Feview, September, 1919.

Irarch, 1939.

October, 1946

September, 1948

October, 1948

Wiscons in Law Review, vol 15, (1931). 


\section{IAAV CASES}

Kentucky State Journal Company v. Workmen's Compensation Board, 101 K. 562, 170 SW 437 (1914)

Iittle Miami F.R. Co. v. Stevens, 20 ohio 4lE, (1851).

Priestley V. Fowler, 3 mees. \& Wels. (Eng) 1, (1837). 
APPENLIX A 


\section{APP IIDIX A}

The purpose of this appendix is to explain the methodology used in this study.

The period frow July 1, 1946 to December 31, 1946 was sel ected for this study because it would give a maximum number of cases which haci been closed or were operating under a definitely agreed upon and approvec open agreement. It is true that a period prior to the last half of 1946 would have given a slightly greater percentage of such cases. Nevertheless if such a period had been selected it would ante-date the amendment to the Act, effective June 19, 1946. This change made the Act virtually compulsory in hazardous occupations and thus greatly increased the number of employers operating under the Act.

Faving selected a period for study mich combined the features of a maximum number of cases operating under signed agreements with the maximum number of employers operating under the Act, it was next desired to select from the cases occurring during this period a sample which woulc be a valid cross-section of the entire universe of between 
9000 and 10,000 , cases occurring auring the period. The Register maintained by the Board was turned to in order to obtain a sample of cases. It was noted that the cases were numbered and entered in the Register in the oraer in which the accident report was received by the Board. The Register showed only the month and day on which the injury occurred, not the date it.was received by the Board. However, only a few of the cases reported to the Board prior to file inumer 500,000 occurred prior to July I, 1946. Therefore this File Number was used as a starting point. Thereafter, a random selection was made of every tenth file number until the File Number 507,000 was reached. By this point there was a sharp increase in incidence of acc1dents occurring after December 31, 1946. Therefore it was felt that approximately $70 \%$ to $75 \%$ of the accidents occurring in the six-month period had been spanned in the selection of the 700 cases from the Register. This percentage is based upon the previously mentioned estimation that between 9000 and 10,000 compensable injuries occurred during the six-month period. 
Once information on the 700 cases had been abstracted from the liegister, an examination was begun of the information abstracted. Of the 700 cases, 49 injuries occurred either before July I, 1946 or after December 31, 1946. In order to maintain consistency these 49 cases were discarded. of the remaining 051 cases, it developed that in 312 cases the Fegister contained only the date of injury and the names of the parties. An examination of the first few of these 312 verified that only an employers report had been filed. Bince neither a preliminary oper agreement nor a final agreement had ever been submitted to the Board these files gave no indication of the probable extent and duration of the disability. It was felt that a detailed examination of these 312 files would be unrewarding due to their fragnentary nature. Therefore an intensive check was made of only the 339 remaining files, in which an agreement had been signed.

However, before the labor of examining these 339 files was begun an effort was made to make a preliminary test of the adequacy of the 330 cases 
abstracted. The age of the worker is entered in the Hegister in ali cases where it is furnished in the accident report. Also the code numbers entered In the kegister after an agreement is aproved show the type of injury and the nature of the injury. In order to test the adequacy of the sample tentatively selected, the methods were used which are outlined by Iyndon 0 . Brown in his book on research. I This work recomended that the three tests of proportionality, cumulative frequency and group rotation be used in testing the reliability of a sample.

The next problem was to decide what factors were of proper significance to the study to warrant their being tested. Age was selected as one because from the time a worler begins earning a living until he is well into midale age he generally undergoes a steady increase in financial responsibilities. The types of injury, such as fatal, permanent partial, etc., was selected because of the 1. Brown, I. J., Karketing Fesearch and Analys is,
$\left(\mathrm{N} . \mathrm{Y}_{.}\right)$, I 37 . 
varying effect on the worker or his family which results from these different tyces of injuries. The nature of the injury, such as an abrasion, a fracture, or an amputation, was selected because injuries differ greatly in their disabling effect and a disproportionate number of any one class would tend to alter the results of the study.

In order to tes.t for proportionality, it was necessary to have sone verified group of statistics against which to compare the sample. The most satisfactory figures for this were to be found in the Annual keport of the Department of Industrial Relations for the fiscal year 1946-47, wich gave statistics based on either the cases reported or the cases closed during the year. Thus an unknown number of injuries occurring prior to July 1, 1946, were included in these statistics. The sample had not included such cases because of the difference in benefit rates and because tie compurs ory feature of the Act were not in effect prior to June 19, 1946. For this reasonslightly different universes were involved. 
The comparis on between the two groups from the standpoint of age was as follows:

\begin{tabular}{l|c|c|c|c|c}
\hline Age & $\begin{array}{l}\text { Feported } \\
\text { in fiscal } \\
\text { year }\end{array}$ & $\begin{array}{l}\text { Percentage } \\
\text { of fiscal } \\
\text { year }\end{array}$ & $\begin{array}{l}\text { Number in } \\
\text { Sample }\end{array}$ & $\begin{array}{l}\text { Percent- } \\
\text { age of } \\
\text { Sample }\end{array}$ & $\begin{array}{l}\text { Differ- } \\
\text { ence }\end{array}$ \\
\hline Under 16 & 8 & 0.04 & 0 & 0.0 & -0.04 \\
$16-18$ & 329 & 1.7 & 8 & 2.4 & +0.7 \\
$19-25 \quad 3215$ & 16.6 & 52 & 15.3 & -1.3 \\
$26-35$ & 5110 & 26.4 & 86 & 25.4 & -1.0 \\
$36-45 \quad 4297$ & 22.2 & 79 & 23.3 & +1.1 \\
$46-55 \quad 3033$ & 15.7 & 58 & 17.1 & +1.4 \\
$56-65 \quad 1466$ & 7.6 & 25 & 7.4 & -0.2 \\
$66-75 \quad 363$ & 1.9 & 6 & 1.8 & -0.1 \\
Over 75 & 36 & 0.2 & 0 & 0.0 & -0.2 \\
Not Givenl461 & 7.6 & 25 & 7.4 & -0.2 \\
\hline
\end{tabular}

of the 9710 cases closed during the fiscal year the figures on the varying types of cases were compared as follows;

\begin{tabular}{l|c|c|c|c|c}
\hline Type Injury & $\begin{array}{l}\text { Closed dur- } \\
\text { ing fiscal } \\
\text { year }\end{array}$ & $\begin{array}{l}\text { Percent- } \\
\text { age of fis- } \\
\text { cal year }\end{array}$ & $\begin{array}{l}\text { imber in } \\
\text { sample }\end{array}$ & $\begin{array}{l}\text { \% of } \\
\text { Sample }\end{array}$ & $\begin{array}{l}\text { Differ- } \\
\text { ence }\end{array}$ \\
\hline $\begin{array}{l}\text { Total } \\
\text { temporary }\end{array}$ & 8218 & 84.6 & 281 & 82.9 & -1.7 \\
$\begin{array}{l}\text { Permanent } \\
\text { partial }\end{array}$ & 1389 & 14.3 & 55 & 16.2 & +1.9 \\
Fatal & 71 & 0.7 & 3 & 0.9 & +0.2 \\
\hline
\end{tabular}


The test for proportionality in the types of cases shows a considerably higher share of permanent partial cases. A factor in this is the fact that it takes much longer to close one of these cases, and it can be assumed that many of the injuries in the annual report occurred during the period prior to the change in the Act, when fewer employers were operating unaer the Act. The cases in the sample all occurred after the change in the Act which increasea conformance by about $30 \%$. When the proportionality was checked on the nature of the injury, the results were as follo:s:

\begin{tabular}{|c|c|c|c|c|c|c|}
\hline Natuie & $\begin{array}{l}\text { inum } \\
\text { fis } \\
\text { yea }\end{array}$ & $\begin{array}{ll}\text { oer } 1.2 \\
\text { cal }\end{array}$ & $\begin{array}{l}\text { Percent- } \\
\text { age of fis- } \\
\text { cal year }\end{array}$ & $\begin{array}{l}\text { wumber in } \\
\text { sample }\end{array}$ & $\begin{array}{l}\text { Fercent- } \\
\text { age of } \\
\text { Sample }\end{array}$ & $\begin{array}{l}\text { Differ- } \\
\text { ence }\end{array}$ \\
\hline \multicolumn{2}{|c|}{ Amputation } & 461 & 2.4 & 14 & 4.0 & +1.6 \\
\hline \multicolumn{2}{|c|}{ Fracture } & 2625 & 13.7 & 50 & 14.7 & +1.0 \\
\hline \multicolumn{2}{|c|}{ Crushed } & 1248 & 0.5 & 26 & 7.6 & +1.1 \\
\hline \multicolumn{2}{|l|}{ Sprain } & 3161 & 16.5 & 53 & 15.6 & -0.9 \\
\hline \multicolumn{2}{|c|}{ Laceration } & 3700 & 19.3 & 63 & 18.6 & -0.7 \\
\hline \multicolumn{2}{|l|}{ Cuts } & 1510 & 7.9 & 22 & 6.6 & -1.3 \\
\hline \multicolumn{2}{|c|}{ Abrasions } & 3780 & 19.7 & 67 & 19.7 & 0.0 \\
\hline \multicolumn{2}{|l|}{ Burns } & 891 & 4.6 & 13 & 3.8 & -0.8 \\
\hline \multicolumn{2}{|c|}{ Unclassified } & 1760 & 9.2 & 31 & 9.1 & -0.1 \\
\hline
\end{tabular}


In all the cases checked for proportionality the variation was less than $2.0 \%$. The next test made was for cumulative frequency. This was purely an internal check and required no ots:er group of statistics for comparison. It was used to see if enough cases were included in the sample and sought to eliminate the posibility of aistortion because the sample mas too small. This test is based on the theory that after a certain point is reached the adition of further cases to the sample will not greatly alter its over-all composition. When this point is reched tivere is no great value in further increasing the size of the sample. In order to make this test the 339 cases in the tentative sample were shuffled several times and then divided into ten Erours of as nearly equal size as posibible. Then some significant factor was selected and a count was made in each group to see how many times this factor had occurred in the groups counted anc what percentage the incidence of occurrence was of the total number of cases counted. In general the anount of variation found in the last half of the cumulative frequency test gives a rough 
approximation of the probable limits of error within the sample. 2

A check was made of the incidence of contusions, which was the most prevalent type of injury and which is an example of a mild injury. The results of a check of the ten groups was as follows:

\begin{tabular}{c|c|c|c|c}
\hline $\begin{array}{l}\text { Group } \\
\text { number }\end{array}$ & $\begin{array}{l}\text { Frequency } \\
\text { of occur } \\
\text { rence }\end{array}$ & $\begin{array}{l}\text { Cumulative } \\
\text { Frequency of } \\
\text { occurrence }\end{array}$ & $\begin{array}{l}\text { Cumulative } \\
\text { number of } \\
\text { cases }\end{array}$ & $\begin{array}{l}\text { Cumulative } \\
\text { percentage of } \\
\text { occurrence }\end{array}$ \\
\hline 1 & 3 & 3 & 34 & $8.8 \%$ \\
2 & 5 & 8 & 68 & 11.8 \\
3 & 10 & 18 & 102 & 17.7 \\
4 & 9 & 27 & 136 & 19.9 \\
5 & 4 & 31 & 170 & 18.2 \\
6 & 9 & 40 & 204 & 19.6 \\
7 & 8 & 48 & 238 & 20.2 \\
8 & 7 & 55 & 272 & 20.2 \\
9 & 6 & 61 & 306 & 19.9 \\
10 & 6 & 67 & 339 & 19.8 \\
\hline
\end{tabular}

A further check was made of the incidence of total temporary injuries throughout the sample with the following results:

2. Brown, Op Cit, pp 312-18. 


\begin{tabular}{c|c|c|c|c}
\hline $\begin{array}{l}\text { Gioup } \\
\text { number }\end{array}$ & $\begin{array}{l}\text { Frequency } \\
\text { of occur- } \\
\text { rence }\end{array}$ & $\begin{array}{l}\text { Cumulative } \\
\text { frequency of } \\
\text { occurrence }\end{array}$ & $\begin{array}{l}\text { Cumulative } \\
\text { number of } \\
\text { cases }\end{array}$ & $\begin{array}{l}\text { Cumulative } \\
\text { percentage of } \\
\text { occurrence }\end{array}$ \\
\hline 1 & 27 & 27 & 34 & $79.4 \%$ \\
2 & 29 & 56 & 68 & 82.3 \\
3 & 29 & 85 & 102 & 83.3 \\
4 & 30 & 115 & 136 & 84.5 \\
5 & 24 & 139 & 170 & 81.8 \\
6 & 26 & 165 & 204 & 80.9 \\
7 & 30 & 195 & 238 & 81.5 \\
8 & 30 & 225 & 272 & 83.0 \\
9 & 28 & 253 & 306 & 83.0 \\
10 & 28 & 281 & 339 & 82.9 \\
\hline
\end{tabular}

A further analysis was made of the total temporary cases in which benefit payments of less than two weeks were paid with the results indicated as follows: 


\begin{tabular}{c|c|c|c|c}
\hline $\begin{array}{l}\text { Grour } \\
\text { Nurbe: }\end{array}$ & $\begin{array}{l}\text { Frequency } \\
\text { of occur- } \\
\text { rence }\end{array}$ & $\begin{array}{l}\text { Cumulative } \\
\text { frequency of } \\
\text { occurrence }\end{array}$ & $\begin{array}{l}\text { Curulative } \\
\text { number of } \\
\text { cases }\end{array}$ & $\begin{array}{l}\text { Cumulative } \\
\text { percentage of } \\
\text { occurrence }\end{array}$ \\
\hline 1 & 13 & 13 & 34 & $38.2 \%$ \\
2 & 16 & 29 & 68 & 42.6 \\
3 & 16 & 45 & 102 & 44.1 \\
4 & 19 & 64 & 136 & 47.1 \\
5 & 14 & 78 & 170 & 45.9 \\
6 & 15 & 93 & 204 & 45.6 \\
7 & 20 & 113 & 238 & 47.5 \\
8 & 14 & 127 & 272 & 46.7 \\
9 & 18 & 145 & 306 & 47.4 \\
10. & 13 & 158 & 339 & 46.0 \\
\hline
\end{tabular}

In all the cases tested by the cumulative frequency method the highest variation in the last hali of the test was 3.1.\%.

The next test used was that of group rotation. It also is designed to test the consistency with which a particular factor occurred throughout the tentative sample. However it goes further than the cumulative frequency method in that the results are checked against a maximum variation which is derived from a statistical formula. The 
number of times the factor appears in the sample atfects the meximum vaciation which is allowable. The workine of the formula as the size of the sample is increasec has been reauced into a table in Bromn's text. 3 This table was relied on in determining the maximum allowable difference in the croup rotation tests. In using this test the sane division of the sample into ten erours of:as rearly equal size as porsible was useo. The ten groups were divided into half in all the five rowible mays and when each separation into two halves was made, the incidence of some factor in each half was counted and the ditrerence of frequency of occurrence in each half was counted and noteä. This aifference in frequercy was then compared with the maximum allowable difference taken from the table in Bromn's text. In each case this last factor was dependent on the proportion of the smallest number of occurrences in one half to half of the whole sample. Tre table showed that as this proportion travelled from $50 \%$ in the airection of either 100\% or zero, the size of the naximum allowable difference decreased. 3. Brown, op Cit, p. 322. 
A test was first made of the distribution of the occurrence of total temporary twoughout the sample and the following results found:

\begin{tabular}{|c|c|c|c|c|c|c|c|c|}
\hline Groups & & $\begin{array}{l}\text { a. of } \\
\text { ur. }\end{array}$ & Grours & $\begin{array}{l}\text { Freq. } \\
\text { occur. }\end{array}$ & of & $\begin{array}{l}\text { Dif. of } \\
\text { occur. }\end{array}$ & $\begin{array}{l}\text { Small- } \\
\text { est of of } \\
\text { occur. }\end{array}$ & $\begin{array}{l}\text { Iax. } \\
\text { Allowable } \\
\text { dif.of } \\
\text { occur. }\end{array}$ \\
\hline 123 & 45 & 139 & 678 & 910 & 142 & 3 & 81.8 & 14 \\
\hline 234 & 56 & 138. & 789 & 101 & 143 & 5 & 81.1 & 14 \\
\hline 345 & 67 & 139 & 891 & 012 & 142 & 3 & 81.8 & 14 \\
\hline 456 & $7 \varepsilon$ & 141 & 910 & 123 & 140 & 1 & 82.7 & 14 \\
\hline 567 & 85 & 138 & 101 & 234 & 143 & 5 & 81.1 & 14 \\
\hline
\end{tabular}

The test for consistency of groups was made for the entire occurrence of contusions:

\begin{tabular}{|c|c|c|c|c|c|c|}
\hline Groups & $\begin{array}{l}\text { Freq. of } \\
\text { occur. }\end{array}$ & Groups & $\begin{array}{l}\text { Freq. of } \\
\text { occur. }\end{array}$ & $\begin{array}{l}\text { Dif.of } \\
\text { occux. }\end{array}$ & $\begin{array}{l}\text { Small- } \\
\text { est } \% \text { oir } \\
\text { occur. }\end{array}$ & $\begin{array}{l}\text { Aax. } \\
\text { Allowable } \\
\text { dif. of } \\
\text { occur. }\end{array}$ \\
\hline
\end{tabular}

$1234531678910 \quad 36 \quad 5 \quad 18.3 \% \quad 15$

$\begin{array}{lllllllllllllll}2 & 3 & 4 & 5 & 6 & 37 & 7 & 8 & 9 & 10 & 1 & 30 & 7 & 17.7 & 15\end{array}$

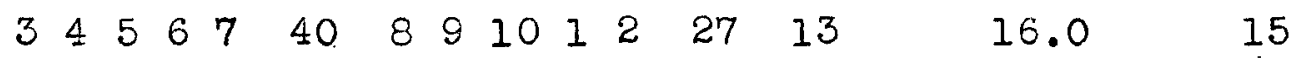

$\begin{array}{llllllllllllll}45 & 6 & 7 & 8 & 37 & 9 & 10 & 1 & 2 & 3 & 30 & 7 & 17.7 & 15\end{array}$

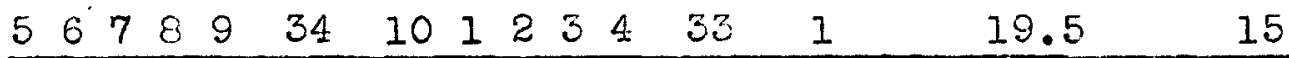

The variations for total temporary cases in which benefit payments were made for two weeks or less was found to be: 


\begin{tabular}{|c|c|c|c|c|c|c|c|c|c|}
\hline Groups & \multicolumn{3}{|c|}{$\begin{array}{l}\text { Frea. of } \\
\text { occur. }\end{array}$} & \multirow{2}{*}{ Grours } & \multicolumn{2}{|c|}{$\begin{array}{l}\text { Ereq. of } \\
\text { occur. }\end{array}$} & \multirow{2}{*}{$\frac{\text { Dif. of }}{\text { occur. }}$} & \multirow{2}{*}{$\begin{array}{l}\text { amall- } \\
\text { est } \% \text { of } \\
\text { occur. }\end{array}$} & \multirow{2}{*}{$\begin{array}{l}\text { Dax. } \\
\text { allowable } \\
\text { dif. of } \\
\text { occur. } \\
18\end{array}$} \\
\hline 123 & 4 & 5 & 78 & & 910 & 80 & & & \\
\hline 234 & 5 & 6 & 80 & 789 & 101 & 78 & 2 & 45.9 & 18 \\
\hline 345 & 6 & 7 & 84 & 8910 & 12 & 74 & 10 & 43.5 & 18 \\
\hline 456 & 7 & 8 & 82 & 9101 & 23 & 76 & 6 & 44.6 & 18 \\
\hline 567 & 8 & 9 & 81 & 1012 & 34 & 77 & 4 & 45.2 & 18 \\
\hline
\end{tabular}

A group rotation was also made of the homogeniety of the occurrence of Fractures throughout trie sample:

\begin{tabular}{|c|c|c|c|c|c|c|c|c|c|}
\hline Groups & \multicolumn{3}{|c|}{$\begin{array}{l}\text { Freq. of } \\
\text { occur. }\end{array}$} & \multirow{2}{*}{$\frac{G r o u p s}{678}$} & \multicolumn{2}{|c|}{$\begin{array}{l}\text { Freq. of } \\
\text { occur. }\end{array}$} & \multirow{2}{*}{$\frac{\left[\begin{array}{l}\text { Dif. of } \\
\text { occur. }\end{array}\right.}{10}$} & \multirow{2}{*}{$\frac{\begin{array}{l}\text { Small- } \\
\text { est } \% \\
\text { occur. of }\end{array}}{12.3 \%}$} & \multirow{2}{*}{$\begin{array}{l}\text { Naximum } \\
\text { allowable } \\
\text { dif. of } \\
\text { occur. } \\
11\end{array}$} \\
\hline 123 & 4 & 5 & 30 & & 910 & 20 & & & \\
\hline 234 & 5 & 6 & 28 & 7897 & 101 & 22 & 6 & 13.5 & 11 \\
\hline 345 & 6 & 7 & 24 & 8910 & 12 & 26 & 2 & 13.2 & 11 \\
\hline 456 & 7 & 8 & 21 & 9101 & 23 & 29 & 8 & 12.9 & 11 \\
\hline $5 \quad 67$ & 8 & 9 & 24 & 1012 & 34 & 26 & 2 & 13.2 & 11 \\
\hline
\end{tabular}

Since none of these tests gave any great indication of unreliability in tre tentatively selected samie, it was decided that it met the various tests of validity. Therefore the 338 files were examined in f'ull and the more detailed irformation talen fro: them. 